\title{
ATEBE
}

Dinî Araștırmalar Dergisi Journal for Religious Studies e-ISSN: 2757-5616

ATEBE Dergisi / Journal of ATEBE

Sayı: 6 (Aralık / December 2021), 53-77.

\section{Klasik İslâm Tarihi Kaynaklarında Nübüvvet Mührü}

The Seal of Prophethood (Khātamu al-nubuwwah) in Islamic Historical Sources

\section{Nejla Ceyhan}

Doktora Öğrencisi, Ankara Üniversitesi, Sosyal Bilimler Enstitüsü, İslam Tarihi Anabilim Dalı Ph.D. Student, Ankara University, Institute of Social Sciences, Department of Islamic History

\author{
Ankara, Turkey \\ ceyhannecla@hotmail.com \\ orcid.org/ 0000-0002-3586-8446 \\ https://ror.org/01wntqw50
}

\section{Makale Bilgisi / Article Information}

Makale Türü / Article Types: Araştırma Makalesi / Research Article

Geliş Tarihi / Date Received: 22 Ağustos/August 2021

Kabul Tarihi / Date Accepted: 20 Aralı/December 2021

Yayın Tarihi / Date Published: 31 Aralı/December 2021

Yayın Sezonu / Pub Date Season: Aralık/December

Atıf / Cite as: Ceyhan, Nejla. "Klasik İslâm Tarihi Kaynaklarında Nübüvvet Mührü". ATEBE 6 (Aralık 2021), 53-77. https://doi.org/10.51575/atebe.985897

İntihal / Plagiarism: Bu makale, iTenticate yazılımınca taranmıştır. İntihal tespit edilmemiştir/This article has been scanned by iTenticate. No plagiarism detected.

Etik Beyan/Ethical Statement: Bu çalıșmanın hazırlanma sürecinde bilimsel ve etik ilkelere uyulduğu ve yararlanılan tüm çalışmaların kaynakçada belirtildiği beyan olunur/It is declared that scientific and ethical principles have been followed while carrying out and writing this study and that all the sources used have been properly cited (Nejla Ceyhan).

Yayıncı / Published by: Ankara Sosyal Bilimler Üniversitesi / Social Sciences University of Ankara. $\mathrm{Bu}$ makale Creative Commons Alıntı-GayriTicariTüretilemez 4.0 (CC BY-NC 4.0) Uluslararası Lisansı altında lisanslanmıştır. This article is an open access article distributed under the terms and conditions of the Creative Commons Attribution-NonCommercial-NoDerivatives 4.0 (CC BY-NC 4.0) International License. 


\title{
Klasik İslâm Tarihi Kaynaklarında Nübüvvet Mührü*
}

\section{Öz}

Nübüvvet mührü; (hâtemü'n-nübüvve) siyer, șemâil, hasâis, delâil türü İslâm Tarihi kaynaklarında yer almış, kimilerince Peygamberimizin nübüvvetinin tasdikinde delil sayılmıștır. Nübüvvet mührü bir alamet olarak Ehl-i kitap mensuplarının kaynaklarında da yer almıştır. Ehl-i kitaba göre, son peygamberin nübüvvet alameti omzu üzerinde, kürek kemikleri arasındadır. Ancak bu alametin mahiyetine dair herhangi başka bir rivayet mevcut değildir. Ehl-i kitap üzerinden aktarılan rivayetlerin nübüvvet mührüne mucizevî bir anlam yüklediğini görmek mümkündür. Rivayetler muvacehesinde Ehli kitap mensuplarından bazıları son Peygamberde bu alameti araştırmış ve bu vesile ile İslâm'la tanıșmıștır. Nübüvvet mührüne dair rivayetler hadis kaynaklarımızda da yer almıștır. Bu rivayetlerin bir kısmı peygamberlik öncesi döneme, bir kısmı ise nübüvvet sonrası döneme aittir. Rivayetlerin nübüvvet sonrasına dair olanlarında, Peygamberimizin çevresinde bulunan ashabınca nübüvvet mührünün bizzat görüldüğü yönünde ifadelere de rastlanmaktadır. İslâm tarihi kaynaklarından İbn Sacd, İbn İshak ve Taberî gibi müellifler nübüvvet mührü rivayetlerine yer vermişlerdir. Nübüvvet mührüne dair rivayetleri kaynaklarımızda; Peygamberimizin doğum hadisesi bölümünde, şakk-ı sadr hadisesi bağlamında, Bedü'l-vahy bâbında, İsrâ ve mi'râc olaylarında Cebrâil ile ilişkilendirilerek ve Peygamberimizin vefatı bașlığı altında Esmâ binti Umeys hadisi vasıtası ile bulmamız mümkün olmuştur. Nübüvvet mührünün özelliklerine dair rivayetlerde dikkat çeken husus Peygamberimizin sırtında iki kürek kemiği arasında irice bir et beninin olduğu vurgusudur. Rivayetlerdeki müșterek nokta burasıdır. Nübüvvet mührünün mahiyeti, ne zaman vurulduğu, neye benzediği konuları da kaynaklarımızda farklı rivayetler doğrultusunda yorumlanmış ve değerlendirilmiştir. Bu bağlamda nübüvvet mührü, İslâm tarihi meseleleri içinde varlığı ve gerçekliği bakımından tartışmalı bir mesele olarak incelenmeyi hak etmektedir. Öte yandan Peygamberimizin ağzından, sırtındaki bu ben hakkında olağanüstülügüne dair açık ifadeler bugüne ulaşmamıştır. Bu konuya dair sahih rivayetler ise sadece nübüvvet mührünün çeşitli tasvirlerini bize aktarmaktadır. Bu tasvirler, görenlerin algısına dayandığı için farklılık arz etse de aşağı yukarı tevhid edilebilecek bir tarif bugün için elimizde mevcuttur. Bu mührü normal bir ben gibi görenlerin yanında mucizevî özellikler atfedenler de vardır. İslâm tarihi içerisinde farklı kabullere ve görüşlere açık bir şekilde değerlendirilmiş olan nübüvvet mührünü, Peygamberimiz hakkında diğer insanlardan farklı mümeyyiz/ayırt edici bir vasıf olarak ele almak; nübüvvet alameti șeklinde ancak fiziksel olarak tabiî bir tarzda kabul etmek gerekir. Kitap ehlinin bu konudaki bekleyiși, gerek hadis gerekse siyer kaynaklarındaki nübüvvet mührü ifadeleri bizi bu noktaya sevk etmiştir.

Anahtar Kelimeler: Siyer, Nübüvvet Mührü, Son Peygamber, Alamet, Mucize.

\section{The Seal of Prophethood (Khātamu al-nubuwwah) in Islamic Historical Sources}

\begin{abstract}
The seal of Prophethood (Khātamu al-nubuwwa) Sìra, Shamā'il, Khasā'is, Dalā'il, genres have been used and utilized within Islamic historical sources as testaments to the prophethood of Muhammad. The Seal of the Prophethood as a sign has also been mentioned within the religious sources of the People of the Book. According to some narrative traditions, a number of the People of the Book have sought out this sign and consequently embraced Islam. There are Muslim traditions that mention the Seal of the Prophet and also mention that it was seen by some of the Companions. These traditions can be found in Islamic historical sources, such as the works of Ibn Sa'd, Ibn Ishāq, and Tabarī, and within the topics that cover the birth of the Prophet, shaqq al-sadr (the splitting of the Prophet's chest), bad' al-wahy (the beginning of revelation), Isrā' wa Mi'rāj (the Nocturnal Journey and Ascendence), and in the hadīth of Asmā b. Umays in the context of Prophet's death. There have been those who have seen it as a hairy spot with a
\end{abstract}

* Bu çalışma 2015 yılında tamamladığımız “Klasik İslam Tarihi Kaynaklarında Nübüvvet Mührü” adlı yüksek lisans tezi esas alınarak hazırlanmıștır./ This article is extracted from my master dissertation entitled "The Seal of Prophethood (Khātamu al-nubuwwah) in Islamic Historical Sources" year 2015. 
Klasik İslâm Tarihi Kaynaklarında Nübüvvet Mührü

mole as well as those who attributed it miraculous properties. Even though there have been varying interpretations on the nature of the phenomenon of this Seal within the Muslim intellectual traditon, it ought to be taken as a distinctive feature of our Prophet and a distinctive physical sign of his prophethood; and the expectations of the People of the Book and the profusion of tradtions within various sources about the Seal of Prophethood have led us to conclude as such.

Keywords: Sīra, The Seal of Prophethood, Mole On Prophet's Back The Sign, Miracle.

\section{Giriş}

Hâtemü'n-nübüvve (nübüvvet mührü) rivayetlerde, Hz. Peygamber'in sırtında kürek kemikleri arasında bulunduğu, boyutu ve şekli üzerinde farklı ifadelerin aktarıldığı, tabiî mi mucizevî mi olduğu tartışılan bene verilen isimdir. Bu ben, mühür (hâtem) olarak adlandırılmış, Peygamberimizin nübüvveti hususunda alametler ve işaretler arasında değerlendirilmiştir. Bu sebeple Peygamberimizin şekli, şemâili, has özellikleri ve nübüvvetinin delilleri üzerine yazılmış birtakım özel alan kitaplarının başlıca konularından bir tanesi olmuştur.

Hadis ve klasik İslâm Tarihi kaynaklarında yer alan bilgilerin yanında Ehl-i kitabın kaynaklarında İncil'de ve Tevrat'ta da yer alan birtakım ifadeler ile Ehl-i kitap mensuplarının bizim kaynaklarımızda yer bulmuş olan rivayetleri, nübüvvet mührünün tarihî gerçekliği noktasında önem arz etmektedir.

Hz. Peygamber'in son nebi oluşu, Ehl-i İslâm'ın kesin şekilde iman etmiş olduğu hususlardandır. Bu husus, nübüvvetin kendisinde mühürlenmiș olduğu șeklinde de ifadesini kaynaklarımızda bulmuştur. Yakın dönem eserlerinde de Hâtemü'l-mürselîn, ${ }^{1}$ hâtemü'n-nebiyyîn ${ }^{2}$ şeklinde nitelendirmeler olmuştur. Bu bağlamda nübüvvet mührü kavramının; bu iki anlamı da -son peygamber ve sırtındaki nübüvvet alameti- taşıyan kullanımı ile yer yer karıştırılmış, birbirinin yerine kullanılmış, eş anlamlı gibi düşünülmüş olduğunu serdeden görüşlerle tarihî süreç içinde karşılaşmaktayız. ${ }^{3}$

Bunun yanında İslâm Dininin mukaddes kitabındaki beyanat doğrultusunda ${ }^{4}$ bütün Müslümanların ortak inancl, ifade ettiğimiz üzere Hz. Muhammed Mustafa'nın peygamberlerin hâtemi olduğu yönündedir. Ancak peygamberlerin sonuncusu oluşunun alameti olarak sırtındaki nübüvvet mührü olarak adlandırılan benin kabul edilip edilmeyeceği İslâm âlimlerince tartışılagelen konulardandır.

$\mathrm{Bu}$ husus dışında nübüvvet mührünün mahiyeti, ne zaman vurulduğu, neye benzediği konuları da kaynaklarımızda farklı rivayetler doğrultusunda yorumlanmış ve değerlendirilmiştir. Bu bağlamda nübüvvet mührü, İslâm tarihi meseleleri içinde varlığı ve gerçekliği bakımından tartışmalı bir mesele olarak incelenmeyi hak etmektedir.

Çalışmamız boyunca "nübüvvet mührü" kavramının kazanmış olduğu yorumları ele almaya ve bu yorumları tarihî gerçeklik doğrultusunda anlamlandırmaya çalışacağız.

Yûsuf b. İsmâil Nebhânî, el-Fedâilü'l-Muhammediyye (Beyrut: ts.), 28.

2 Kur'ân-ı Kerîm Meâli, çev. Halil Altuntaş - Muzaffer Şahin (Ankara: Diyanet İşleri Başkanlığı Yayınları, 2009) el-Ahzâb 33/40.

3 Mustafa Sinanoğlu, "Nübüvvet Mührü", Türkiye Diyanet Vakfi Íslâm Ansiklopedisi (Ankara: TDV Yayınları, 2007), 23/291.

4 el-Ahzâb 33/40.

https://dergipark.org.tr/tr/pub/atebe 
Mesele klasik kaynaklarımızda ele alınmakla birlikte hakkında günümüzde Erdinç Ahatlı dışında münhasıran çalışılmamış olmasına binaen farklı bir bakış açısı ile özellikle görünümü ve delaleti bakımından ele alınmayı beklemektedir. Bu bağlamda temel bazı sorulara cevap arayacağız. Nübüvvet mührü ismiyle bilinen bir "ben"in peygamberlik alametleri arasında klasik kaynaklarımızda zikredilmesi hangi bağlamda olmuştur? Hakikatte bu bir alamet midir? Yoksa sadece beșerî, fitrî bir "ben" midir?

Ehl-i kitabın kaynaklarında, hadis kaynaklarımızda ve sonraki dönem İslâm Tarihi eserlerinde yer bulan ancak günümüzde tek tük çalışmanın ötesinde ele alınmadığını gördüğümüz nübüvvet mührüne dair ele alacağımız meseleler ve sonuçlar hazırlamış olduğumuz yüksek lisans tezine ${ }^{5}$ dayanmaktadır. Çalışmamızda nübüvvet mührünün kaynaklarımızda hangi șekillerde ve anlamlarda ele alındığı mukayeseli bir yöntem ile değerlendirilecektir. Ve bu yöntemle "nübüvvet mührü" kavramının çerçevesini çizmeye çalışacağız. Bu bağlamda anlamsal bir kargaşa içinde gibi duran farklı yaklaşımların beșerîdir/nebevîdir, alamettir/bendir, doğuştandır/sonradan vurulmuştur gibi- tevhidi mümkün müdür? Yoksa "nübüvvet mührü" kavramının kullanımındaki ortak ifade benzerliği ve yüklenen anlam farklılarından kaynaklanan bir takım karışıklıkların mı olduğunu incelemeye çalışacağız. Bu konuda Erdinç Ahatlı'nın makalesi başvuracağımız temel çalışma olsa da Ahatlı'nın ele alış tarzından daha farklı bir şekilde mesele değerlendirilecektir. Ahatlı'nın makalesinde çerçeve nübüvvet mührünün olağanüstülüğü meselesine, zamansal planda ortaya nasıl çıktığına, var oluş zamanına yoğunlaşmışken bizim çalışmamızda, daha kronolojik bir ele alışla mesele işlenecektir. Ehl-i kitabın bilgisi, hadis ve klasik İslam tarihi kaynaklarındaki rivayetlerin ele alınmasının ardından fiziksel varlığının nasıllığının değerlendirilmesi sonrasında beşerî / nebevî yönlerinin delalet boyutuyla ele alınması planlanmaktadır. Kavramın netleşmesi ve kullanım alanının belirlenmesi hususunda katkı sunmasını temenni ettiğimiz çalışmamızda, nübüvvet mührünün bütün cihetlerden hüviyetine uygun șekilde tespiti amaç edinilecektir.

\section{Kitâb-ı Mukaddes'e Göre Beklenen Son Peygamber ve Alametleri}

Ehl-i kitap, Kitâb-ı Mukaddes'te yer alan bilgiler doğrultusunda, tarif edildiği üzere gelecek olan bir peygamberden haberdardır. Hem Tevrat'ta hem de İncil'de İsrailoğulları'na gönderilmiş olan gelmiş geçmiş birçok peygamberin son nebiyi, hâtemû'n-nebiyyîni farklı isimlerle; bazen açıkça, bazen de işaret yoluyla müjdelediklerini görmekteyiz. Yahudi kutsal kitabı olan Tanah'ın Tekvîn bölümünde Hz. İbrâhim'inn ${ }^{6}$ ve Hz. Ya'kûb'un7 "Şilo" ismi ile son olarak gelecek peygamberi müjdeledikleri ve milletlerin itaatinin O'na olacağını haber verdikleri görülmektedir. Hz. Musa'nın diliyle de, "Onlar için kardeşleri arasından senin gibi bir peygamber çıkaracağım ve sözlerimi onun ağzına koyacağım. Ve ona emredeceğim her şeyi onlara söyleyecek.." şeklinde geleceği beklenen

\footnotetext{
Nejla Ceyhan, Klasik İslam Tarihi Kaynaklarında Nübüvvet Mührü (Konya: Necmettin Erbakan Üniversitesi, Sosyal Bilimler Enstitüsü, Yüksek Lisans Tezi), 2015.

6 Kitab-ı Mukaddes (İstanbul: Boyacıyan Agop Matbaası, 1949) Yar. 12:1-3.

Yar.49:10.

Yas.18:18.
} 
son nebi / Peygamberimiz müjdelenmiştir. Dâvûd (a.s), ${ }^{9}$ Daniel (a.s), ${ }^{10}$ ve Habakkuk ${ }^{11}$ daha sonra gelecek olan peygamberi kinâyeli bir şekilde müjdelemişlerdir.

İncil'de Yuhanna kitabında yer alan; "Onlar da kendisinden sordular: Öyle ise ne? Sen İlya mısın? Ve Yahyâ: Değilim, dedi. Sen o peygamber misin? Yahyâ: Hayır diye cevap verdi."12 ifadesi ayrıca; "Benden sonra gelen O'dur. Ben O'nun çarığının bağını çözmeye layık değilim." 13 ifadesi ve; "Benden sonra bir adam geliyor ki, benden ileri oldu, çünkü benden önce idi, diye söylediğim adam budur."14 ifadeleri Yahyâ (a.s.)'ın kendisinden sonra gelecek olanı açıkça beyan ettiğini göstermektedir. Yuhanna İncili'nde bu hususta başka âyetler de mevcuttur. Bu âyetler içerisinde beklenen kişinin özellikleri farklı şekillerde ifade edilmektedir. Yuhanna İncili'nde yer alan geleceği "tesellici", "selamet"15 ve "hakikat ruhu" şeklinde nitelenen müjdecinin Tevrat'ta ise "acip öğütçü", "Kadir Allah", "ebediyet babası", "selâmet reisi" isimleri ile isimlendirildiğini görmekteyiz. Ehl-i kitap âlimleri, tarihî süreçten de bildiğimiz üzere bu ifadeleri "kutsal ruh" yahut gelişini bekledikleri "mesîh" şeklinde yorumlamaktadır. ${ }^{16}$ Bu ifadeler açıkça ve farklı nitelemeler yoluyla gelişi kesin olan birine, bir peygambere, kurtarıcıya veyahut müjdeciye delalet etmektedir.

Bu rivayetler içerisinde konumuzla daha yakından alakalı olan bir âyet ise Kitab-ı Mukaddes'te İşaya kitabında yer alır. Ayette, "omzu üzerinde olacak"17 ifadesinin Tevrat'ta yer alan benzer bir ifade ile örtüştüğü görülmektedir. Tevrat'ta bu ayet şu şekilde yer almaktadır: "Çünkü bize bir çocuk doğdu bize bir oğul verildi ve reislik onun omzu üzerinde olacak ve onun adı; 'acip öğütçü', 'Kadir Allah', 'ebediyet babası', 'selâmet reisi' olarak çağırılacaktır."18 Ali b. Rabben et-Taberî̀ye göre, Tevrat'ın İşaya kitabında yer alan bu ifade, "Çünkü bize bir çocuk doğdu, bize bir oğul verildi. Sultanlığı onun kürek kemikleri üzerindedir."19 şeklindedir. Ali b. Rabben et-Taberî, "Sultanlığı onun kürek kemikleri üzerindedir." ifadesinin İbranîce ve Süryanîce metinlerinde sarahaten "Kürek kemiği üzerinde nübüvvet alameti vardır." şeklinde yer aldığını ayrıca ifade etmektedir. ${ }^{20}$

Zikretmiş olduğumuz rivayetlerde son peygamber bilgisinin Ehl-i kitap tarafından bilindiği aşikârdır. Ancak bütün bu rivayetler içerisinde son zikrettiğimiz omuzları üzerinde nübüvvet mührü olduğu yaklaşımı ve bilgisi, nübüvvet mührünün bir alamet olarak İslâm öncesi dönemde de bilinen ayırıcı bir vasıf olduğunu göstermektedir. Ayrıca özellikle Ali b. Rabben et-Taberî gibi erken dönem müelliflerinden, hem de Hristiyan iken Müslüman olan Ehl-i kitap kaynaklarına vukûfiyeti birinci elden gerçekleşen birinin sarih bir ifade ile "kürek kemiği üzerinde nübüvvet alameti vardır" şeklinde ayeti İbranîce ve

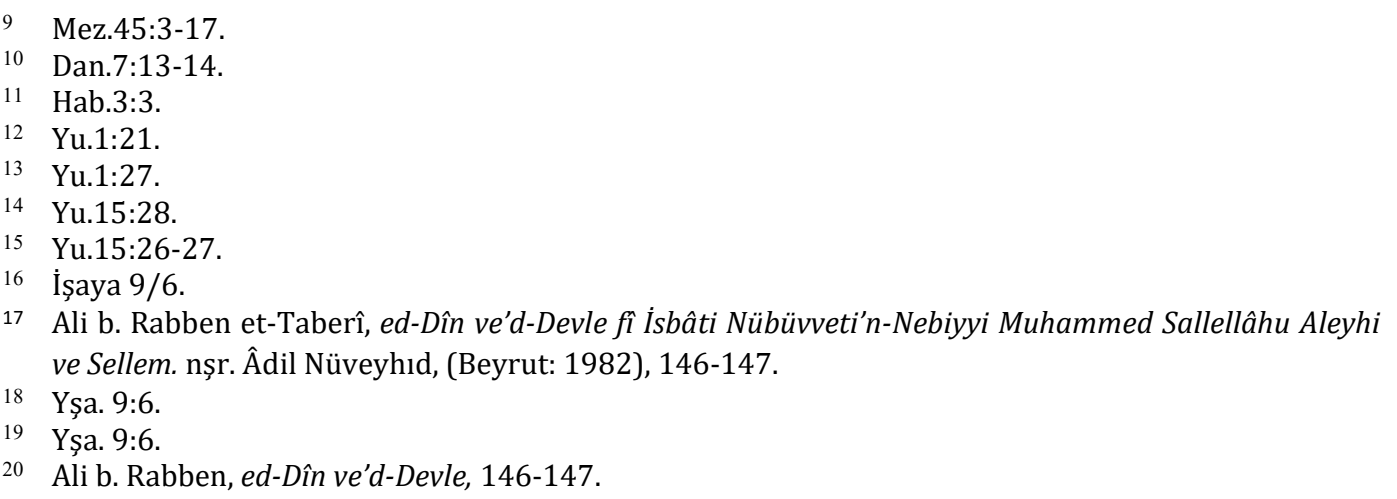


Süryanîce metinlere atıfla açlklaması nübüvvet mührünün Ehl-i kitap nazarındaki mahiyeti hususunda aydınlatıcı bir bilgidir. Ayrıca Ali b. Rabben, ehl-i İslâm arasında da Peygamberimizin bu sıfatı ile ma'rûf olduğu ve bunun Ahzâb sûresindeki 40. ayette geçen "peygamberlerin sonuncusu" ifadesi ile delillendirildiği bilgisine de yer vermektedir. ${ }^{21} \mathrm{Bu}$ konu ile ilgili olarak ilahî kitaplarda yer alan Peygamberimizin isimlerine dair rivayetleri İslâmî kaynaklarda da bulmak mümkündür. Şöyle ki; "sultanlı̆̆ı kürek kemikleri üzerindedir" ifadesi Tevrat ve İncil'de geçtiği şekline benzer bir şekilde İslâmî kaynaklarda da yer almıştır. Peygamberimizin isimleri arasında "sultan" ismine de yer verilmiştir. Ve "sultan" ismi ile "hâtemü'n-nübüvve" isimleri yer yer yan yana zikredilmiştir. $^{22}$

Velhasıl İncil'de ve Tevrat'ta yer alan son peygamberin varlığından bahseden ayetler içerisinde müjdelenen bir nebinin varlığı rivayetlerde açıkça görülmektedir. Gelecek peygamberin tanıtıcı vasfı olarak sırtındaki nübüvvet mührünün kabulü bizim kaynaklarımızın bazılarında yer alan yaklaşım ile de örtüşmektedir. Görüldügü kadarıyla Ehl-i kitaba göre, son peygamberin nübüvvet alameti omzu üzerinde, kürek kemikleri arasındadır. Ancak bu alametin mahiyetine dair herhangi başka bir rivayet mevcut değildir. Yukarıda sorduğumuz sorulara Ehl-i kitap rivayetlerinde cevap bulmak mümkün görünmemektedir. Bizim kaynaklarımızdaki tarifi ise ilerleyen satırlarda ele alınacaktır.

\section{1. İslâm Tarihi Kaynaklarında Ehl-i Kitaba Nispet Edilen Rivayetlere Göre Son Peygamber Bilgisi ve Nübüvvet Mührü}

Ehl-i kitabın mukaddes kitaplarındaki rivayetleri yukarıda zikrettikten sonra İslâm Tarihi kaynaklarımızda yer alan Ehl-i kitaba mensup kişilerden nübüvvet mührünü görenlerin ve bilenlerin olduğu yönündeki rivayetlere de yer vermemiz konu bütünlüğü bakımından gereklilik arz etmektedir. Dikkat edilmelidir ki rivayetler burada serd edilirken kronolojik sıra gözetilecektir.

Evvela kaynaklarımızda Peygamberimizin dedesi Abdülmuttalib'in dahi nübüvvet mührü ile dünyaya gelecek bir nebiden Hıristiyan bir devlet adamı vasıtası ile haberdar olduğu yönünde bizi üzerinde düşündürecek bir rivayeti ele almak gerekir. Kâbe'yi yıkmak niyeti ile fillerden ordu hazırlayarak Mekke'ye gelen ve mağlup olup hezimete uğrayan Ebrehe'den sonra Yemen'de kral olan Seyf b. Zûyezen'i, ${ }^{23}$ Abdülmuttalib Kureyş'in önde gelenlerinden oluşan bir heyet ile ziyarete gitmiştir. Bu ziyaret esnasında Abdülmuttalib'e Yemen'in yeni kralının söylediği sözler, yeni gelecek son peygamber hakkında birçok bilgiye sahip olduğunu göstermektedir. Seyf b. Zûyezen, "Tihâme'de bir çocuk doğduğunda, kürek kemikleri arasında ben bulunacak. Bu ben onun alameti olacak ve kıyamete kadar liderlik onun elinde olacak." demiştir. Bu çocuğun doğduğunda adının Muhammed olacağını, annesi ve babasının vefat edeceğini, O'na kefil olacakların dedesi ve amcası olacağını, putları kırıp, ateşi söndüreceğini" söylediği de rivayetlerde mevcuttur. Hatta Abdülmuttalib'in "adını Muhammed koyacaklarını ve doğmasını bekledikleri bir çocuğun olduğunu" söylemesi üzerine Seyf b. Zûyezen'in "doğacak olan

21 Ali b. Rabben, ed-Dîn ve'd-Devle, 147.

22 Mercânî, Behcetü'n-Nüfûs ve'l-Esrâr. (Mısır: Dâru'l- Garbi'l-İslâmî, 2002), 2/693-695.

23 bk. İbn Asâkir, Sîretü'n-Nübüvve'sinde Seyf b. Zûyezen'in asıl ismi hakkında İbn Munzur'un "Onun ismi Numân'dır." dediğini aktarır. (3/250) 
bu çocuğu Yahudilerden saklamasını çünkü onların düşmanlıklarının olacağını" söylediğini rivayetler bize aktarmaktadır. ${ }^{24}$

Seyf b. Zûyezen'in Abdülmuttalib'e "kürek kemikleri arasında ben olacak" şeklinde bir tarif vermiş olması yukarda zikrettiğimiz İşaya kitabında yer alan rivayetin yaygın șekilde bilindiğini ve bu alametin ayırıcı vasıflar arasında bulunduğunu göstermektedir.

Bir bașka rivayette ise Mekke'de meskûn olan, ticaretle iștigal eden bir Yahudi'nin, Kureyş'te oturan bir topluluğun yanına gelerek "Bu gece sizden birinin çocuğu dünyaya geldi mi?" diye sorması, bu doğan çocuğun son ümmetin nebisi olduğunu, alametinin de omuzları arasındaki etrafı tüylü bir ben olduğunu söylemesi üzerine Kureyş araștırma yaparak bazı rivayetlerde Abdülmuttalib'in, bazı rivayetlerde ise Abdullah'ın bir oğlunun dünyaya geldiğini haber vermesi anlatılır. Çocuğun isminin Muhammed olduğunu öğrenen Yahudi, çocuğu görmek istemiş ve ilk baktığı şey sırtındaki alamet olmuştur. ${ }^{25}$

Rivayet mantık olarak sorunlu durmaktadır. Çocukluk, gençlik yahut peygamberliğine kadar ki yetişkinlik sürecinde Kureyş'in tutumunda bu bilgi sebebiyle değişiklik olduğu yönünde Yahudi'nin rivayetini destekler nitelikte başka bir rivayet kaynaklarımızda yer almamıștır.

Bunun gibi sütannesinin yanında iken gerçekleștiğini bildiğimiz iki rivayet mevcuttur. Peygamberimiz daha süt çocuğu iken Zü’l-mecaz panayırında bir arrâfın oradaki çocuklar arasından Peygamberimize ayrıca bakarak hâtemü'n-nübüvveyi görüp Arap topluluğuna seslendiği, "Bu çocuğu öldürün, çünkü o sizin ilahlarınıza ve dininize galip gelecek, putlarınızı yıkacak." dediği șeklindeki rivayet ile; Vâdîl-surur isimli Mekke'ye 4 mil uzaklıktaki bölgede (Mekke vadisi civarı) Hz. Halime'nin yanında Peygamberimiz bulunduğu halde Habeş'ten bir nefer ile karşılaşınca neferin bir takım sorular sorup önce Peygamberimize sonra da sırtındaki nübüvvet mührüne baktığı ve bunun üzerine "Vallahi bu nebidir." diyerek haber verdiği rivayetidir. ${ }^{26}$

İlk rivayeti ele aldığımızda "Sırt bölgesinde olduğu bilinen nübüvvet mührünü arrâf, çocuğa bir bakışta nasıl görmüştür?" sorusu hemen akla gelmektedir. Hz. Halime, çocuk ile ilgili arrâfla hiç bir şey konuşmamış herhangi bir bilgi vermemiş olmasına rağmen arrâf bütün çocukları gözden geçirerek kendisinde nübüvvet mührü olan çocuğu niçin tespit etme ihtiyacı hissetmiştir? Yahut arrâf, kendisine gelip fal baktıranların dışında çevresindekilere son peygamberi arayan bir gözle neden bakmıştır? Metin bu açılardan mantık yönüyle zayıflık taşımaktadır. İkinci rivayette ise Habeşli neferle $\mathrm{Hz}$. Halime'nin karşılaşma sebebi ne olabilir? Nefer her yoldan geçen çocuğun sırtında nübüvvet mührü mü aramaktadır? Yahut nübüvvvet mührünü taşıyan çocuğun bilinebileceği yüzünde de bir işaret olmalı değil midir? Bir yolculuk; herhangi bir yolcu ile herhangi bir neferin yollarını bu tarz bir mevzuda sohbet edecek şekilde nasıl

24 Beyhakī, Delâilü'n-Nübüvve ve Ma'rifetü Ahvâli Sâhibi'ş-Şerîa. nşr. Abdülmu'tî Kal'acî, (Beyrut: 1985), 2/11-13; İbn Asâkir, es-Sîretü'n-Nebeviyye. (Beyrut: 2001), 3/250-252; Halebî, İnsânü'l-Uyûn fî Sireti'l-Emîni'l-Me'mûn. (Kahire: 1292), 1/187.

25 Beyhakī, Delâilü'n-Nübüvve, 1/108-109; İbn Asâkir, es-Sîretü'n-Nebeviyye, 3/236; İbn Kesîr, el-Bidâye ve'n-Nihâye, 3/42-43; Halebî, İnsânü'l-'Uyûn, 1/112; Mercânî, Behcetü'n-Nüfus, 2/679.

26 Ebû Nuaym, Delâilü'n-Nübüvve, nșr. Muhammed Ravvâs Kal'acî-Abdülber Abbâs. (Haleb: Dâru'nNefâis, 1999), 160; Halebî, İnsanü'l-Uyûn 1/156. 
kesiştirmiştir? soruları cevaplarını rivayetlerin içinde bulamamaktadır. Rivayetlerin mantıksal dokuları bu anlamda destekleyici, anlamı tamamlayıcı başka unsurlardan uzaktır.

Buna benzer bir başka rivayette ise Hz. Peygamber, sütannesinin yanından annesi Amine'nin yanına geldikten bir müddet sonra altı yaşlarında iken Medine'de bulunan dayılarının yanına giderken yanlarında dadısı Ümmü Eymen de bulunduğu halde bir Yahudi'nin Peygamberimizi tanımasından bahsedilir. Yahudi Peygamberimize ismini sormuş ve sırtını açarak bakmıştır. Bunun üzerine bu çocuğun ümmetin nebisi olduğunu annesine haber vermiştir. ${ }^{27} \mathrm{Az}$ önce zikrettiğimiz soruların benzerleri bu rivayet için de geçerlidir. Yahudilerin haberdar oldukları bu mevzuları Kureyş'e haber vermelerine rağmen Kureyş'te herhangi bir tavır değişliğine kaynaklarımızda rastlamadığımızı söylemiştik. Varsayalım ki Yahudilerden, ümmetin nebisinin çıktığı ve kendi kabilelerine mensup olduğu haberini alan Kureyş'in herhangi bir araştırma içerisine girmemiş olması, Yahudileri dahi yakından ilgilendiren, bekleyiş içinde bulundukları ve yıllar boyu araştırdıkları son peygamberin bilgisini aşikâr etmelerine rağmen Kureyş tarafında herhangi bir aksin meydana gelmemiş olması akla muhaliftir.

Ehl-i kitabın nübüvvet mühründen haberdar oluşu ile ilgili kaynaklarımızdaki en bilindik rivayet Rahip Bahîrâ rivayetidir. ${ }^{28}$ Rivayette Bahîrâ'nın sorduğu bir takım sorular ve aldığı cevaplar yer almaktadır. Bu sorulara bu cevapları verebilecek gözleri kırmızı, sırtında gerdek çadırı düğmesine benzeyen bir ben bulunan bir başka yetim çocuk daha olması mümkündür. Bu rivayet yaşanmış olsa da rahip Bahîrâ'nın bu alametlerle ilgili kesin bir yargı ortaya koymuş olması, daha peygamberlikle vazifelendirilmemiş bir çocuk için resul ifadesini kullanması, hakkında kabilesine kanaat bildirmesi pek makul değildir.

Kādî İyâz, Şifâ isimli eserinde, "Peygamberimiz'in Peygamberliğini Gösteren ve Birer Alamet Teşkil Eden Deliller Hususundadır" başlığı altında, Ehl-i kitabın bilgisinden bahsetmiş ve bunu nübüvvet delilleri arasında şöyle zikretmiştir:

\begin{abstract}
“Birçok rahip ve kitab ehlinin bilgini O'nun şeklinden, ümmetinin niteliklerinden, O'nun ismi ve işaretlerinden hatta iki omzu arasında bulunan nübüvvet mühründen söz etmişlerdir. Eski muvahhidlerden Tubbâ, Ebs b. Harise, Ka'b b. Luey, Süfyan b. Mücaşî, Kuss b. Saide gibi şahısların irat ettikleri şiirlerinde bile ismi geçmiştir. Amr b. Nufeyl, Varaka b. Nevfel ve Uskelân el- Hümeyrî gibi kimselerin de onun geleceğinden haberleri vardır. Yahudi bilginleri arasında bilhassa Tubbâ'nın arkadaşı olan Yahudi bilginlerinden Şamûl de müteaddid defa Resullullah'ın geleceğini söylemiştir. Onlardan İbn Selâm, Beni Sa'ye, İbn Yamin, Muhayrîk, Ka'b gibi İslâmiyeti kabul eden zevât da Tevrat'ta ve İncil'de son peygamber hakkındaki haberleri gördüklerini söylemişlerdir. Buheyra (Bahîrâ), Nastura, Değatır, Şamın uskufu, Cârut, Selmân, Necaşî, Necrân'ın uskufları ve Nasrânî âlimleri hep O'ndan bahsetmişler ve evsafını Tevrat'ta ve İncil'de gördüklerini açıklamışlardır."29
\end{abstract}

27 Ebû Nuaym, Delâilü'n-Nübüvve, 163; Kuşeyrî, Menâhilü'ş-Şifâ ve Menâhilü's-Safâ bi-Tahkikî Kitabi Șerefi'l-Mustafâ, (2003), 1/386.

28 Ebû Nuaym, Delâilü'n-Nübüvve, 181; İbn Seyyidünnâs, 'Uyûnü'l-Eșer fî Funûnu'l-Meğâzî ve'ş-Şemâil ve's-Siyer. nşr. Muhammed el-Iydu'l-Hatrâvi-Muhyîddin Mestû, (Beyrut: 1992), 1/107.

29 Kādî İyâz, Kitabü'ş-Şifâ bî Târîfi Hukûki'l-Mustafâ. (Beyrut: 2000), 455-457. 
Hz. Peygamber'in çocukluğunda yaşanan nübüvvet mührünün görülerek peygamberliğine ispat teşkil ettiğini ifade eden bu hadiseler görüldüğü üzere muhteliftir. Rivayetlerde yer alan Ehl-i kitap mensuplarının son peygamberin geleceğinden haberdar oluşlarına ve bu peygamberin bir takım alametlerini bilip ayrıca bunları, Hz. Peygamber üzerinde tetkik ettiğine dair rivayetler, klasik İslâm tarihi eserlerinde birçok farklı olay bağlamında değişik zamanlarda gerçekleşmiş olarak yer edinmiştir.

Rivayetlerde çeşitlilik ve zamansal olarak birbirinden bağımsızlık söz konusudur. Bununla birlikte rivayetler içerik itibariyle benzer yönlere sahiptir. Ana tema aynıdır.

Bu noktada sonuç olarak nübüvvet mührünün bir alamet olduğu ve son nebinin ayrıcı vasfı olduğu bilgisi, birbirini destekleyen rivayetlerin kutsal kitaplardaki bütünlüğü sebebiyle kabul edilmelidir. Rivayetler benzer ve birbirini destekleyici niteliktedir.

\subsection{Selmân-ı Fârisî’nin Nübüvvet Mührünü Görerek Müslüman Olması Meselesi}

İlk başlarda Zerdüşt dinine mensup iken sonraları Hıristiyanlığı benimseyen ve Hıristiyan bir papazın tavsiyesi ile İbrâhim peygamberin dini üzerine gönderilecek Arapların bölgesinde zuhur edecek bir peygamberden haberi olan Selmân-ı Fârisîî (r.a.) hakkındaki meşhur rivayet, "nübüvvet mührünün" kitap ehlince bilindiğinin ve bu mühre sahip bir peygamberin geleceğinden haberdar olduklarının işaretlerindendir.

Yine İran'ın resmî dini olan Zerdüştlüğe mensup iken sonraları Isfahan'da bulunan bir Hıristiyan papazın vesilesiyle Hıristiyanlığı benimseyen Selmân-ı Fârisî, bu papazın ölmeden önce yaptığı tavsiye ile Musul'daki bir bașka rahibin yanına ve Musul'daki rahibin de tavsiyesi ile Nusaybin'e, Nusaybin'deki rahibin de tavsiyesi ile Ammûriye'ye gider. Ammûriye'deki rahibin hizmetinde bulunur ve en son olarak bu rahip ölüm döșeğinde iken kendisine İbrâhim peygamberin dini üzere gelecek olan son peygamberden ve bu peygamberin Arapların bölgesinden zuhur edeceğinden bahseder. ${ }^{31}$ Ayrıca Ehl-i kitap tarafından son peygamberin alametleri arasında olduğu bilinen bir takım özelliklerden bahseder. Bu peygamberin özellikleri olarak iki kürek kemiği arasında olan "nübüvvet mührü"nden tanınacağını, hediye kabul ettiğini ancak sadaka kabul etmediğini, peygamber olduktan sonra doğduğu topraklardan çıkarılacağını, hurmalık bir bölgeye hicret edeceğini haber verir.

Selmân-ı Fârisî (r.a) bir iş nedeniyle gittiği Medine'de, Hıristiyan rahip tarafından kendisine hurmalık bir bölgeye hicret edeceği söylenilen son peygamberin bu şehre hicret ettiğini öğrendiğinde son peygamberin yanına giderek rahipten öğrendiği bilgileri sınamıştır, yine rahiplerden duymuş olduğu "nübüvvet mührü"nü görmek istemiş, Peygamberimizin bizzat sırtını açarak mührü kendisine göstermesi ile bilgilerinin

30 Selmân-ı Fârisî hakkında daha geniș bilgi için Bkz., Şihâbüddin Ebü'l-Fadl Ahmed b. Ali b. Hacer elAskalânî, el-İsâbe fî-Temyîzi's-Sahâbe, (Beyrut: Dâru'l-Kütübi'l-i̇lmiyye, 2005), 3/118-119; Mâlik b. Enes, el-Müsned li-Muvatta, (Beyrut: 2000), 1/267.

31 Muhammed b. İshak b. Yesâr İbn İshak, Sîretü İbn İshak el-Müsammâ bî Kitabi'l-Mübtede' Ve'l-Meb'as ve'l-Meğazî, nşr. Muhammed Hamidullah (Konya 1981), 68-69; Ebû Muhammed Abdülmelik İbn Hişâm, es-Sîretü'n-Nebeviyye, thk. Mustafa es-Sekkâ-İbrahim el-Ebyarî-Abdülhafîz Şelebî (Beyrut: 1992), 1/175-176.

https://dergipark.org.tr/tr/pub/atebe 
doğruluğunu görerek Müslüman olmuştur. ${ }^{32}$ Rahipten aldığı bilgileri sınaması hususunda Ahmed b. Hanbel'in Müsnedi'nde açık ifadeler vardır. ${ }^{33}$

Ayrıca Mevâhib şarihi de eski kitapların âlimlerinin Hz. Peygamber'in alametleri arasında sayılan nübüvvet mührünü bildiklerini söyleyerek bu hususta Selmân-ı Fârisi'nin öğrendiklerini Peygamberimizin önce haline sonra sırtına bakarak gözlemlediğini zikretmektedir. ${ }^{34}$ Selmân-ı Fârisi'nin rivayetini diğer Ehl-i kitap rivayetlerinden ayıran çok önemli husus da budur. Selmân-ı Fârisi, nübüvvetin alametlerini artık peygamber olduğu aşikâr biri üzerinde teyit etmektedir. Bu gayet normaldir. Selmân-ı Fârisi'nin rivayetini ayrı bir başlık altında ele alma sebebimiz de aslında budur.

Ehl-i kitabın bilgisine dair zikrettiğimiz rivayetlerin Selmân-ı Fârisi rivayeti ile ardıl şekilde ele alınması bize çocuk yaşta iken gerçekleştiğini bildiğimiz rivayetlerin teyidi imkânını vermektedir. Selmân-ı Fârisi rivayetinde, önce araştırılan ve teyit edilen peygamberlere has bir takım özellikler mevcuttur. Sonra bu özelliklere ek olarak nübüvvet mührü görülmek istenilmektedir. Bu rivayet bu cihetler ile makuldür. Yukarıda zikrettiğimiz kaynaklarımızdaki Ehl-i kitabın rivayetleri, mührü destekleyen nebevî bazı özelliklerin çocuk yaşta bulunmayışı sebebiyle görenlerin farazî yorum ve bakışları olarak kalmakta idi. Bu minvalde Selmân-ı Fârisi rivayeti ile yukarı bölümde zikrettiğimiz rivayetlerin destek/karşllık bulduğunu söyleyebiliriz.

\section{Hadis Kaynaklarında Nübüvvet Mührü Rivayetleri}

İsnadı Peygamberimize ulaşan -merfû- hadislerde nübüvvet mührü hakkında bilgi bulunmamaktadır. Öte yandan muhtelif kimselerin farklı hadiseler sebebiyle Peygamberimizin sırtında gördüklerini söyledikleri, nübüvvet mührü diye niteledikleri ben ile karşılaştıklarına dair rivayetlerin klasik hadis kaynaklarımızda yer aldığını görüyoruz. Genellikle hadis kitaplarının şemâil ve menâkıb bâblarında yer alan rivayetleri, nübüvvet mührünün tarihî gerçekliğini anlamamızda taşıdığı önem bakımından burada değerlendirmeye çalışacağız.

Buhârî el-Câmî'u's-Sahîh'in “Kitâbu'l-Menâkıb" bölümünde 'Alâmâtü'n-nübüvve fi'lİslâm ismini verdiği başlık altında hacimli bir şekilde konuyla ilgili olarak elliden fazla rivayet kaydetmiştir. Bu rivayetlerden biri şöyledir:

Abdurrahman b. Yûnus, Hâtim b. İsmail'den o da Ca'd'dan rivayetle şöyle demiştir: "Ben Sâib b. Yezîd'den işittim şöyle diyordu: Teyzem beni Peygamber'in (s.a.v) yanına götürdü ve: Yâ Resulallah! Benim kız kardeşimin bu oğlu ayağından rahatsızdır, dedi. Resûlullah başımı eli ile sıvazladı ve bana bereket duası etti. Sonra abdest suyundan içtim. Sonra sırtının arkasında dikeldim ve iki omzu arasında gerdek çadırının büyük düğmeleri

32 İbn İshak, Sîretü İbn İshak, 68-69; İbn Hişâm, es-Sîretü’n-Nebeviyye, 1: 177; Beyhakī, Delâilü’nNübüvve, 2/82-91, 95, 97; Abdurrahman b. Abdullah Süheylî, er-Ravżü'l-ünüf fî Tefsirîs-Sîreti'nNebeviyye ve Me'ahu's-es-Sîretü'n-Nebeviyye, thk. Abdullah el-Minșâvî (Kahire:2008), 1/408-415; Zehebî, Tarîhu'l-İslâm, 1/95-102; Muhammed b. Abdülbâkî Zürkānî, Şerhu'l-Mevâhibü'l-Ledünniye, $1 / 289$.

33 Ebû Abdillâh Ahmed b. Muhammed b. Hanbel eş-Şeybânî Ahmed b. Hanbel, el-Müsned, (İstnabul:1331), 5/354-438-441-444.

34 Zürkānî, Şerhu'l-'Allâme ez-Zürkānî 'ale'l-Mevâhibü'l-Ledünniye li'l-Kastalânî, (Beyrut, 1996), 1/289. 
- yahud keklik yumurtası - gibi (zirru'l-hacele) peygamberlik mührünü gördüm."35 Buhârî, Tirmizî ve Müslim hadislerinde aynı senedin kullanıldığı görülmektedir. Tirmizî hadisin akabinde hadisin hasen, sahîh, garîb olduğunu ifade etmiş ve ziyadede bulunmuştur. Demiştir ki: "ez-Zirru, beyazlık" demektir. ${ }^{36}$

Bu rivayette iki omzu arasında bir beyazlık şeklinde yer alan benzetme, Müslim'in rivayetinde teninin rengine yakın ve direkt mühür kelimesi ile yapılmıștır. Ayrıca rivayetlerde yer alan keklik yumurtası ve güvercin yumurtası benzetmeleri yakınlık taşımaktadır. Rivayet şu şekildedir:

Müslim "Bâbu İsbâtı hâtemû'n-nübüvve ve sıfatihi ve mahallehu min cesedihi (s.a.v)" isimli bâbta, Câbir b. Semure rivayetine yer verir.

(...) Bize Muhammed b. Müsennâ rivayet etti. Dedi ki bize Muhammed b. Ca'fer rivayet etti. Bize Şu'be, Simâk'dan rivayet etti. Dedi ki Câbir b. Semûre'yi dinledim. Ben Resûlullah'ın iki omzu arasındaki nübüvvet mührünü tıpkı güvercin yumurtası gibi bir mühür şeklinde gördüm. Rengi de kendi bedeninin rengine yakındı. 37

Yine Müslim aynı bölümde başka bir hadise yer vermiştir ki bir önceki rivayette nübüvvet mührünün rengi, beden rengine uygun bir renk șeklinde benzetme bulurken bu rivayette "kırmızıya çalar beyazdı" şeklinde benzetmeye konu olmuştur.

Bize Yahyâ b. Eyyûb ve Kuteybe b. Saîd ve Ali b. Hucr da rivayet ettiler. Dediler ki: Bize İsmail (yani İbn Ca'fer) rivayet etti. Bana Kâsım b. Zekeriyya dahi rivayet etti. Dedi ki: Bize Hâlid b. Mahled rivayet etti. Dedi ki: Bana Süleyman b. Bilâl rivayet etti. Her iki râvi Rabîa'dan (yani İbn Ebî Abdirrahman'dan) o da Enes b. Mâlik'den naklen Mâlik b. Enes'in hadisi gibi rivayette bulunmuşlardır. Bunların hadislerinde "kırmızıya çalar beyazdı" ziyadesi vardır. ${ }^{38}$

Tirmizî’nin Sünen'inde bulunan rahip Bahîrâ hadisesine de değinmek gerekmektedir. Rahip Bahîrâ'nın rivayette geçen "Onu iki kürek kemiği arasındaki bir meyve büyüklüğündeki peygamberlik mühründen de tanıdım." ${ }^{39}$ sözleri ölçüsel anlamda bir tarif verse de diğer rivayetlerin metinlerinde yer alan görüntüsü ile ilgili bilgi içermemektedir. Aynı rivayet içerisinde Rahip Bahîrâ'nın son nebi hakkında bazı endișelerini zikretmesi üzerine Ebû Tâlib, peygamberi götürmekten vazgeçip Ebû Bekir ve Bilâl ile geri göndermeye karar vermiştir.40

Tirmizî bu hadis hakkında "hasen garibtir" demiştir.

35 Ebû Abdullah Muhammed b. İsmâil Buhârî, el-Câmi'u's-Sahîh, (İstanbul: 1979), "Vudû"' 40; Ebü'lHuseyn Müslim b. Haccâc el-Kușeyrî en-Nîsâbûrî Müslim, el-Câmi'u's-Sahîh, nşr. Nezr Muhammed elFâryâbî (Dâru't-Taybe: y.y, 2006), "Fedâil”, 111; Ebû Îsâ Muhammed b. İsâ Tirmizî, Sünenü't-Tirmizî, (İstanbul: Çağrı Yayınları, 1981), "Menâkıb", 11.

36 Buhârî, "Vudû'”, 40; Müslim, "Fedâil”, 111; Tirmizî, "Menâkıb”, 11.

37 Müslim, "Fedâil", 110.

38 Müslim, "Fedâil", 113.

39 Mithat Eser, “Hz. Peygamber'in Bir Bulut Tarafından Gölgelenmesine Dair Rivayetlerin Değerlendirilmesi", İslamî Araştırma Dergisi 22/1 (2011), 45.

40 Tirmizî, "Menâkıb", 3; Ebu'l-Fidâ İsmâîl b. Ömer el-Dımeşkî İbn Kesîr, el-Bidâye Ve'n-Nihâye, (Mısır: 1932), 3/ 70-72; İhsan Arslan, "Vahiy Bağlamında Rahip Bahîrâ Olayının Değerlendirilmesi”, Recep Tayyip Erdoğan Üniversitesi Sosyal Bilimler Dergisi 4/8 (2018), 332. 
Zehebî, Tarîhu'l-İslâm'ında etraflıca İbn İshak'tan gelen rivayet çerçevesinde Rahip Bahîrâ hadisine yer vermiştir. ${ }^{41}$ Ancak hadisin "onunla beraber Ebû Bekr ve Bilâl'i gönderdi" ifadesi sebebiyle münker olduğunu söylemiştir.42

İbn Kesîr rivayeti zikrettikten sonra hadiste, birtakım garabetlerin mevcut olduğundan bahseder. Olayı Ebû Musa el-Eş’arî'nin görmesinin mümkün olmadığını ve hadiseyi kimden duyduğunu da söylemediğini, bulutun gölgelemesi kısmının sahîh olmadığını, Hz. Ebû Bekr ile Hz. Bilâl'in yaşça yakın oluşlarını ve küçük yaşta bulunmalarını dile getirir. ${ }^{43}$

Nübüvvet mührü ile ilgili hadisler Ahmed b. Hanbel'in Müsned isimli eserinde de çok sayıda hadis rivayeti ile yer almıştır. Burada mevzumuz açısından önem arz eden birkaç tanesini almakla iktifa edeceğiz:

İbn Ömer ve's-Selmâ Utbe b. Abd es-Sülemî'den rivayet etmiștir. Adamın biri sordu senin işinin evveli nasıldı ya Resûlullah? dedi ki: Ben Benî Sa'd b. Bekr içerisinde idim. Ben onların çocukları ile birlikte iken dışarı çıktık. Kartal görünümlü iki beyaz kuş geldi. Onlardan biri diğerine dedi: 0, 0 mudur? Diğeri evet dedi. Ağzını açar açmaz beni kaptı. Sonra beni yanım üzere yere yatırdı. Karnımı yardı. Kalbimi çıkardı. Kalbimi de yardı. Siyah bir kan pıhtısı çıkardı. Onlardan biri diğerine: Bana kar suyu getir! dedi, onunla yıkadı. Sonra soğuk su istedi onunla da kalbimi yıkadı. Sonra kalbime sekineti doldurdu. Sonra hâtemü'n-nübüvve ile mühürledi. ${ }^{44} \mathrm{Bu}$ rivayet nübüvvet mührünün görünümü ile ilgili bir benzetmeye yer vermemekle birlikte sütannenin yanında iken nübüvvet mührünün vurulduğunu ve önceki rivayetlerin metinlerinden farklı olarak omuzları arasına değil de kalbine vurulduğunu belirttiği için diğer rivayetlere muhalif noktalara haizdir.

Ahmed b. Hanbel'in Müsned'inde yer alan bir başka rivayet ise şöyledir:

“Ebû Kâmil Hammâd'dan (yani İbn Zeyd) Hammâd Süveyd b. Saîd'den, Saîd Ali b. Müshir'den, her iki râvi ise Âsım el-Ahvel'den rivayette bulunmuştur. Bana Hamid b. Ömer el-Bekrâvi dahi rivayet etti. Lafız onundur. Dedi ki: Bize Âsım, Abdullah b. Serciş'den rivayet etti. Dedi ki: Peygamberi gördüm. Onunla ekmek ve et yedim. (Yahut tirit yedim, demiş). Râvi demiş ki ona: Peygamber senin için istiğfar etti mi? diye sordum. "Evet! Senin için de, dedi." Sonra şu ayeti okudu: "Günahın için istiğfar et! Erkek ve kadın mü'minler için de." ${ }^{45}$ Abdullah dedi ki: Sonra arka tarafına dolandım. Ve iki omzunun arasındaki nübüvvet mührüne baktım. Sol küreğinin başında parmakları bir araya getirilmiş yumruk gibi. Üzerinde siğiller vardı." ${ }^{46}$

$\mathrm{Bu}$ rivayetin bize aktardıklarında da önce zikretmiş olduğumuz rivayetler cihetinden uzak benzetmeler görülmektedir. "Parmakları bir araya getirilmiş yumruk gibi" ifadesi yumurta benzetmelerine yakındır. Siğillerin varlığı ise bu hadiste karşımıza çıkmış, metindeki değişik ifadelerdendir.

41 Ebû Abdullah Şemsüddin Muhammed b. Ahmed b. Osman Zehebî, Târîhu'l İslâm ve Vefeyâtu'l-Meşâhîr Ve'l-A'lâm, nşr. Ömer Abdü's-Selâm Tedmurî (Beyrut: 1994), 1/57-60.

42 Zehebî, Tarîhu'l-İ́slâm, 1/57.

43 İbn Kesîr, el-Bidâye ve'n-Nihâye, $3 / 73$.

44 Ahmed b. Hanbel, el-Müsned, 4/185.

45 Muhammed 47/19.

46 Ahmed b. Hanbel, el-Müsned, 5/83; Müslim, "Fedâil”, 112; es-Süyûtî, Hasâis, 49-50. 
Ahmed b. Hanbel'in Müsned'inde Ebû Rimse hadis başlığının altında da bir rivayet mevcuttur. Ebû Rimse, Teymu'r-Rebâb kabilesindendir. Rivayetlerden tabip ve cerrah olduğunu anladığımız Ebû Rimse, Müslüman olduktan sonra kendisi gibi tabip olan babası ile Peygamberimize gelmiştir. Güvercin yumurtası büyüklüğünde omuzları arasında yağ kistine benzettiği bir parça görmüş ve cerrahî bir müdahale ile o kisti almak istemiştir. Peygamberimizle aralarında geçen konuşmadan Peygamberimizin bu teklifi reddettiğini ve "sen tabip değil refîksin, tabip ise onu yaratan Allah'tır." diyerek mukabelede bulunduğunu öğrenmekteyiz. ${ }^{47}$ Tirmizî, Ebû Rimse et-Teymî̀nin asıl adının Habîb b. Hayyân yahut Rifâ'a b. Yesribî olduğunu söyler. ${ }^{48}$ Ebû Davud da Ebû Rimse hadisine Sünen'inde yer vermekte rivayeti metin bakımından değişiklik olmaksızın aktarmaktadır. 49

Bu rivayetin az çok benzerinde Benî Âmir kabilesine mensup bir başka tabip Hz. Peygamber'e gelerek sırtındaki 'hâtim' i görmüştür. Kendisinin Arapların en iyi doktoru olduğunu ve bu beni tedavi etmek istediğini söylemiștir. Bunun üzerine Peygamberimiz bu teklifi de kabul etmemiștir. ${ }^{50}$ Rivayetin devamında Peygamberimizin bu adamdan karşıdaki hurma dalını yanına çağırmasını istediği adamın da bu isteğe riayet ederek ağacı yanına çağırdığı ve ağacın adamın yanına gelerek geri döndüğü bilgisi de Peygamberimizin gösterdiği bir mucize olarak yer almaktadır. ${ }^{51}$ Rivayet el-Hasâis' de de yer almaktadır ancak bu rivayetin içinde Benî Âmir'den bir adamın gelip Peygamberimizi tedavi etmek istemesinden bahsedilirken nübüvvet mührü ifadesinin rivayetin içinde yer almadığı görülmektedir. Ağacı çağırması ve ağacın geriye gitmesi mucizesi de rivayette yer alır. Ancak nübüvvet mühründen bahseden bir içeriğe Süyûtî yer vermemiştir. ${ }^{52}$

Daha önce zikretmiş olduğumuz hadislerle Peygamberimizin sırtındaki benin tedavi girişimlerine dair Ebû Rimse ve Benî Âmir kabilesine mensup bir başka tabip rivayetleri mukayese edildiğinde daha önceki rivayetlerin içeriğinde hiç rastlamadığımız bir değerlendirme olarak Peygamberimizin sırtındaki benin hastalık emaresi bir kist şeklinde yansıtıldığını görmekteyiz. Önceki rivayetlerde metinler arasında mevcut küçük farklılıklar dikkat çekiyordu. Ancak burada bütün rivayetler bir arada değerlendirilince büyük bir farklılık gözlemleniyor. Şöyle ki; nübüvvet mührü bir alamet olmaktan çıkıp tedavisi gereken bir kiste dönüşüyor.

Kâdî İyâz'ın Şifâ'sında rastlayıp hadis kitaplarında bulamadığımız ilginç bir hadisi/ rivayeti de burada aktarmak istiyoruz. Müzenî, Cabir b. Abdullah'tan şöyle rivayet etmiştir: "Peygamber sallallahu aleyhi vessellem beni devesinin arkasına aldı, nübüvvet mührünü ağzıma aldım. Bana misk gibi kokuyordu." ${ }^{3}$ Rivayette insanoğlunun yapmakta makul görülmeyeceği bir tavır ile karşılaşıyoruz.

Bu bağlamda Mevlana Şiblî̀nin, Asr-ı Saadet isimli eserindeki şu tetkiki mevzumuz dâhilinde bulunduğundan burada zikredilmelidir. Mevlana Şiblî hadis kaynaklarında yer

47 Ahmed b. Hanbel, el-Müsned, 2/227-228; Beyhakī, Delâilü'n-Nübüvve, 1/265.

48 Tirmizî, "Edeb", 48.

49 Süleyman b. Eş'as es-Sicistânî Ebû Dâvud, Sünenü Ebî Davud, (İstanbul: 1981), "Teraccül”, 18.

50 Ebû Ca'fer Muhammed b. Cerîr et-Taberî, Târîhu't-Taberî (Târîhu'l-Ümem Ve'l-Mülûk), nşr. Muhammed Ebu'l-Fadl İbrâhîm (Beyrut: t.s), 2/297.

51 Taberî, et-Tarih, 2/297.

52 Süyûtî, Hasâis, 91.

53 Kâdî İyâz, eş-Şifa, 107. 
alan çeşitli rivayetlerin olduğundan bahsederek "Doğru ve sağlam bütün rivayetlerin tetkikinden peygamberlik mührünün siyah benlerden müteşekkil, üzeri kıllı büyük bir ben olduğu anlaşılıyor." ifadelerine yer verir. Öte yandan bazı rivayetlerde yer alan nübüvvet mührünün üzerinde şehadet kelimesinin yazılı olduğu iddiasını tamamıyla esassız sayar. Hadisçilerin hadd-i zâtında bu rivayetleri teyit ve tasdik etmediklerini de ekler. Bu gibi sözleri zayıf ve bâtıl addeder. Resul-i Ekrem'in mektupları mühürlemek için kazdırdığı mühürün üzerinde şehadet kelimesinin yazılı olduğunu birçoklarının bu mühür ile sırtındaki beni karıştırdıklarını iddia eder. 54

Velhasıl hadisleri bir bütün halinde gözden geçirdiğimizde Hz. Peygamber'in kendi ağzından bu yönde "nübüvvet mührü" şeklinde bir ibarenin çıkmadığını müşahede ederiz. Ancak hadis ravilerinin kendi müşahedelerini aktardıkları birçok hadis ile kaynaklarda karşılaşmaktayız. Bu hadisler; Buhârî, Müslim, Tirmîzi ve Ahmed b. Hanbel gibi hadis otoritelerinin Ehl-i sünnetçe kabul görmüş kitaplarında yer edinmişlerdir. Ancak bu yer ediniş ifadelerin bazılarında garipliklerin olmasına mani değildir elbette. Rivayetler ve değerlendirmeleri ışığında iki görüşü yani kabul ve red görüşlerini benimseyenlerin olabileceği açıktır. Bizim bu bağlamdaki görüşümüz ise nübüvvet mührünün rivayetlerde açık ifadeler ile yer almış olması ve Hz. Peygamber ifade etmemiş olsa bile yakınlarından görenlerin ve tarif ederek rivayet edenlerin varlığı sebebiyle hakikatte olduğu yönündedir.

\section{Nübüvvet Mührünün Rivayetlerde Yer Alan Özellikleri}

Siyer kaynaklarımızda, Hz. Peygamber'in nübüvvetini ve nübüvvet özelliklerini ele alan delâil, şemâil ve hasâis türü eserlerde mevcut bilgiler ışığında nübüvvet mührünün özellikleri ile ilgili açıklayıcı bilgilere ulaşmak mümkündür.

Hadislerde olsun siyer kaynaklarında olsun nübüvvet mührü ile ilgili rivayetlerde nübüvvet mührünü görenlerin nerdeyse her birinin kendi müşahedesine uygun bir benzetmede bulunduğunu görmekteyiz.

Hz. Peygamber'in siyer ve megāzîsiyle ilgili en hacimli ve kapsamlı eserlerden biri olan Sübülüll-hüdâ ve'r-reșâd'ın yazarı, Süyûtî'den şeyhimiz diye bahseden Şemseddin Şâmî, Hz. Peygamber'in kürek kemikleri arasında yer alan mührün neye benzediği ile ilgili toplam yirmi bir rivayete yer vermiștir ${ }^{55}$ ve bu rivayetlerin birçoğunun kaynaklarını da belirtmiştir. Bu yönüyle çaplı bir araştırma ortaya koyan Şâmî, rivayetleri sıhhat bakımından tetkike tabi tutmamıștır. ${ }^{56} \mathrm{Bu}$ rivayetlerin ardından tenbihât adı altında nübüvvet mührünün $\mathrm{Hz}$. Peygamber'in sırt bölgesinde omuzları arasında nerede bulunduğu ile ilgili rivayetleri değerlendirmiştir. İmam Müslim'in Sahîh'inde sol omzuna yakın olduğu hususunda bilgi yer aldığını Selmân rivayetinde ise sağ omuz ifadesinin geçtiğini aktarmıştır. ${ }^{57}$ Nübüvvet beninden maksadın ne olduğu hakkındaki yorumlara da

54 Mevlana Şiblî Numanî, Âsr-ı Saadet, çev. Ömer Rıza Doğrul (İstanbul: Eser Neşriyat, 1978), 2/7.

55 Erdinç Ahatll, "Nübüvvet Mührü", Sakarya Üniversitesi İlahiyat Fakültesi Dergisi/3 (2001), 282.

56 Muhammed b. Yûsuf es-Sâlihî Muhammed b. Yûsuf es-Sâlihî Şâmî, Sübülü'l-Hüdâ ve'r-Reşad fî Sîrati hayri'l-lbâd nșr. Mustafâ Abdülvâhid (Kahire: 1990), 2/63-68.

57 Şâmî, Sübülü'l-Hüdâ, 2/68. 
bu başlık altında değinmiş, şeytanın vesvesesinden masumiyet manasına geleceği yolundaki rivayetleri de aktarmıştır. ${ }^{58}$

Nübüvvet mührü; Buhârîdde keklik yumurtası, gerdek çadırının düğmesi,59 Müslim'in hadisinde siğil,60 bir başka rivayette ise sol kürek kemiğinin civarında kıkırdak $^{61}$ veya güvercin ${ }^{62}$ şeklinde benzetmelere konu olmuştur. Rahip Bahîra hadisinde de rastladığımız gerdek çadırı şeklindeki ibareye birçok kaynakta da rastlanmaktadır. ${ }^{63}$

Nübüvvet mührü; kuş yumurtalarından güvercine ${ }^{64}$ kekliğe $^{65}$ benzetildiği gibi devekuşu yumurtasına da benzetilmiştir.66 "Atın gözlerinin arasındaki beyazlık" benzetmesi de yapılmıștır. ${ }^{67}$ Dişi keçi gerdanına benzetildiği de ayrıca rivayetler arasında yer almıştır.68 Ancak bu rivayeti kaydeden Şâmî, rivayetin senedinin zayıf olduğunu aktarmıştır.69

İbn Hacer Eşrefü'l-Vesâil İlâ Fehmi'ş-Şemâil isimli eserinde nübüvvet mührüne dair rivayetlerin birçoğuna tahlil ederek yer vermiştir.70 Beyhakî de Delâil'inde nübüvvet mührünün çeşitli özelliklerinden ve raviler kanalıyla gelen benzetmelerinden bahsetmektedir. Özel bir bâb başlığı altında nübüvvet mührünü ele almıştır. Diğer rivayetlerde ele aldığımız "gerdek çadırı düğmesi", "güvercin yumurtası", "siğile benzer", ifadelerine ek olarak bu bâb başlığı altında "et parçası", "kan alma aletinin izi" benzetmelerini içeren rivayetleri de bulabilmekteyiz. ${ }^{71}$

Zürkānî, Şerhû'l-Mevâhib'te hadis kaynaklarında hangi muhaddisin hangi rivayet ile nübüvvet mührünün neye benzetilerek rivayet edildiğini sıralamıştır.72 Zürkânî bunları sıralarken Tirmîzî'deki rivayette güvercin yumurtasına benzetildiğini söyledikten sonra nübüvvet mührünün bâtınında "Allahu vahdehû lâ şerîke leh, zâhirinde ise Sen mansûr kılındığın şeye yöneleceksin" diye yazıldığını da aktarır. ${ }^{73}$ Ancak bu rivayet münferittir. Ve bir benin üzerinde bu ibarenin nasıl yer alacağı hususu anlaşlır değildir. Ayrıca güvercin yumurtasına benzetilen rivayet Süyûtî'nin Hasâis'inde de yer bulmuştur.74 Süyûtî siğile benzetildiği şeklinde gelen rivayete ve toplanmış kıllar şeklindeki rivayete de yer vermiștir. ${ }^{75}$

Şâmî, Sübülü'l-Hüdâ, 2/69.

9 Buhârî, “Vudụ̂””, 40; Tirmîzî, “Menâkıb”, 11; Zürkānî, Mevâhibü'l-Ledünniye, 1/290.

Müslim, "Fedâil", 112.

Zürkānî, Mevâhibü'l-Ledünniye, 1/290.

62 Ahmed b. Hanbel, el-Müsned, 5/107.

63 İbn İshak, Sîretü İbn İshak, 54-55; İbn Hişâm, es-Sîretü'n-Nebeviyye, 1/48; Ebû Hâtim Muhammed b. Hibbân b. Ahmed el-Büstî İbn Hıbban, es-Sîretü'n-Nebeviyye ve Ahbârü'l-Hulefâ' (Beyrut: 1987), 5859; Ebu'l-Feth Muhammed b. Muhammed el-Yemurî İbn Seyyidünnâs, 'Uyûnü'l-eser, 1/105-111.

64 Buhârî, "Kitâbu'l-Menâkıb", 22.

65 Müslim, "Fedâil", 112.

66 Şâmî, Sübülü'l-Hüdâ, 2/67.

67 Buhârî, "Kitâbu'l-Menâkıb", 22.

68 Şâmî, Sübülü'l-Hüdâ, 2/66.

69 Șâmî, Sübülü'l-Hüdâ, 2/66.

70 İbn Hacer, Eşrefü'l-Vesâil ilâ Fehmi'ş-Şemâil, nşr. Muhammed Ali Beydûn (Beyrut 1998), 80-93.

71 Beyhakī, Delâilü'n-Nübüvve, 1/259-267.

72 Zürkānî, Mevâhibü'l-Ledünniye, 1/290-293.

73 Zürkānî, Mevâhibü'l-Ledünniye, 1/293.

4 Süyûtî, Hasâis, 49.

75 Süyûtî, Hasâis, 50. 
Bunun gibi farklı bir benzetmenin yer aldığı başka bir rivayet ise tabib Ebû Rimse et-Teymînnin Peygamberimize gelerek sırtındaki "kisti" almak istemesi hadisesinde yer almıştır.76 Zehebî bu "kist" hakkında tarifte bulunarak "cildi ile eti arasında bir beze" ifadesini kullanmıştır.77

Şu'be Simâk'tan gelen bir rivayette ise Resûlullah'ın iki omzu arasındaki nübüvvet mührünün güvercin yumurtası gibi olduğu ve renginin kendi cesedinin rengine yakın olduğu şeklinde tarif vardır. ${ }^{78} \mathrm{Bu}$ rivayette dikkat çeken husus yukardaki rivayetlerden farklı olarak nübüvvet mührünün rengine dair açılklayıcı bilginin mevcudiyetidir. Ravi görgüsü doğrultusunda nübüvvet mührünün renginin Peygamberimizin ten rengine yakın olduğunu ifade etmiştir. Müslim'in Enes b. Mâlik'ten gelen rivayetinde ise "kırmızıya çalan beyazdı" ziyadesi yer almaktadır.79 Bu rivayet Tirmizîde "kırmızı et parçası" şeklinde yer almıştır. Burada da renk bakımından kırmızılığının vurgulandığını görmekteyiz. ${ }^{80} \mathrm{Bu}$ iki renk benzetmesinin dışında rivayetler içerisinde bir de "siyah-kara" benzetmesi mevcuttur. ${ }^{81}$ Nübüvvet mührünün rengi ile ilgili zikredilen renkler her ne kadar farklı farklı ise de bahsi geçen üç rengin de ben rengi olabileceği göz önünde tutulur ise rivayetler mantık dâhilindedir. Malum olduğu üzere zaman içerisinde insan vücudundaki benlerin renk değiştirme ihtimali vardır. Bu sebeple zaman içerisinde Peygamberimizin sırtında bulunan benin rengi değişmiş ve rivayetlerdeki farklılık bu sebeple belirmiş olabilir.

Nübüvvet mührü ile ilgili yiyecek türleri içerisinde ise üç tür benzetme ile karşılaşmaktayız ki bunlar "fındık", 82 elma ${ }^{83}$ ve incir84" şeklinde rivayetlerde yer almaktadır. Zehebî elma ifadesi geçen Ahmed b. Hanbel'in yer vermiş olduğu hadisi hakkında "isnadı sahîhtir" demiştir.85

Rivayetler gözden geçirildiğinde nübüvvet mührü benzetmelerinin hiç birinde açıkça bir boyut ifadesinin yer almadığını görürüz. Ancak ifadeler de yer alan elma, fındık ifadeleri hudutları belli olmayan bir takım boyutları akla getirmektedir. Öte yandan kist, beze gibi benzetmeler de bize boyutu hakkında net bir malumât vermemekte, aşağı yukarı bir tarif olarak sinırlı kalmaktadır.

Nübüvvet mührünün özelliklerine dair zikretmiş olduğumuz rivayetlerde (görgü tanıklarının benzetmelerinde) dikkatimizi çeken Allah Resulü'nün sırtında iki kürek kemiği arasında irice bir et beninin olduğu vurgusudur. Rivayetlerdeki müşterek nokta burasıdır. Denilebilir ki bunun dışında gerek rengi noktasında, gerek şekli söz konusu olduğunda, gerekse boyutu mevzusunda yahut niteleyici başka herhangi bir vasfında ittifak edilen başka bir özellik mevcut değildir. Bu aslında doğal bir sonuçtur. Elimizdeki bilgiler görgü tanıklarının rivayetlerine dayandığı için, bu tanıkların bakış açılarındaki

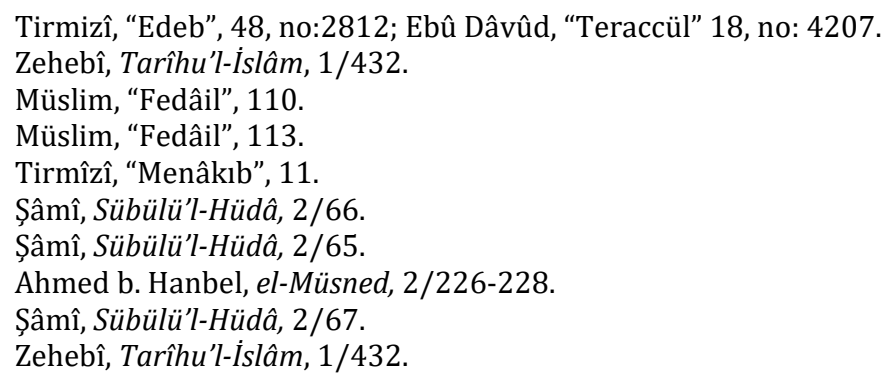


farklılıklar müşterek bir nitelemeye imkân vermemekte ancak aşağı yukarı benzer tabirler ile görmeyenler için bir resim çizmektedir.

\subsection{Nübüvvet Mührünün Doğuștan Olduğunu Söyleyen Rivayetler}

Hz. Peygamber'in doğumunda bir takım mucizevî olayların yaşandı̆̆ siyer kaynaklarında yer almaktadır. Peygamberimizin doğumunda annesinin doğum sancısı çekmediği, doğduğunda sünnetli doğduğu, melekler tarafından yıkandığı, iki omzu arasına gelmek üzere sırtına risâlet mührünün vurulduğu rivayet edilmektedir.86 Görüldüğü gibi bu rivayette doğarken mühürle doğmadığı mührün sonradan vurulduğu aktarılmaktadır.

Nübüvvet mührünün varlığı ile ilgili olarak iki ayrı görüş mevcuttur ki biri mührün doğuştan var olduğunu diğeri ise sonradan vurulduğunu beyan etmektedir.

Ancak nübüvvet mührünün doğuştan olduğunu söyleyen rivayetler kaynaklarımızda oldukça sınırlıdır. Bu rivayetler içerisinde bir Yahudi'nin Peygamberimizin sırtındaki mührü doğduğu gece müşahede etmesi yer alır. Hz. Peygamber'in doğumu esnasında Mekke'de bulunan bir Yahudi'nin Kureyș halkından bazı kişilere gelerek "Bu gece sizden birinin çocuğu dünyaya geldi mi?" diye sorduğu ve Abdülmuttalib'in oğlunun dünyaya geldiğini duyması üzerine doğan çocuğu görmek istediği gelmektedir. Bu isteğine icabet olunmuş ve Peygamberimizin sırtındaki mührü görerek peygamberliğin İsrailoğulları'ndan gittiğini söylemiștir. ${ }^{87}$ Elimizde direkt doğumla ilgili olan tek rivayet bu olduğundan rivayetin tahlili bu bağlamda önem kazanmaktadır. Buhârî, bu hadisin senedinde yer alan Ebû Gassân Muhammed b. Yahyâ el-Kinânî'den Mâlik ve Zührî yoluyla hadisi nakletmiștir. ${ }^{88}$ Buhâri'de yer alan bu hadisin metin bakımından ele alınması durumunda çelişkili birtakım durumlar söz konusu olmaktadır. Rivayete göre Kureyș'in son peygamberin doğumuna şahitliği ve Yahudi'nin bu husustaki kelamı, beyanı söz konusudur. Bu durumda Kureyş'te bu haberin yaygınlaşması, bir takım şeylerin değişmiş olması gerekirdi. Düşündürücüdür ki Peygamberimizin doğumundan vahyin başlangıcına kadar süre gelen bu süreç içerisinde tarihî kaynaklara yansımış hiçbir rivayet mevcut değildir. Köklü Arap şiiri içerisinde dahi olsa tarihe kaynaklık edecek küçük bir rivayete rastlanmış değildir. Bu hususta metin bakımından bizi aydınlatacak, rivayeti destekleyecek başka rivayetten de yoksunuz.

Beyhâkînnin Delâil'inde, ${ }^{89}$ Ebû Zer hadisinde ${ }^{90} \mathrm{~Hz}$. Peygamber'in dünyaya sırtında nübüvvet mührü vurulu iken geldiği rivayetleri mevcuttur.

Şimdi ele alacağımız rivayetlerde ise nübüvvet mührünün sonradan mı doğuştan mı vurulduğu mevzusu tartışmalı bir içeriğe sahiptir. Bu rivayetler, Yahudi'nin haberindeki gibi açık bir içeriğe sahip değiller.

86 Ebu'l-Hasen Ahmed b. Yahyâ b. Câbir b. Dâvud Belazürî, Ensâbü'l-Eşrâf, thk. Muhammed Hamidullah (Misir:1959), 162.

87 Beyhakī, Delâilü'n-Nübüvve, 1/108-109; İbn Asâkir, es-Sîretü'n-Nebeviyye, 3/236; İbn Kesîr, el-Bidâye ve'n-Nihâye, 3/42-4; Halebî, İnsânü'l-Uyûn, 1/112; Mercânî, Behcetü'n-Nüfus ve'l-Esrâr, 2/679.

88 Zehebî, Mizânü'l-I'tidâl fí Nakdi'r-Ricâl, (Beyrut ts.), 4/62.

89 Beyhakī, Delâilü'n-Nübüvve, 1/108-109.

90 İbn Asâkir, es-Sîretü'n-Nebeviyye, 3/261.

https://dergipark.org.tr/tr/pub/atebe 
Kaynaklarımızda yer alan Bahîrâ hadisesi ilk bakışta Peygamberimizin sırtında kürek kemikleri arasında olduğu bilinen nübüvvet mührünün doğuştan olduğunu düşünmeye bizi sevk eder. Fakat nübüvvet mührünün doğuştan olduğunu vurgulayan rivayetler arasında sayılmaya da sayılmamaya da müsait bir yapıdadır. Çünkü sütannenin yanında iken yaşadığı şakk-ı sadr rivayeti ve bu rivayetin içerisinde nübüvvet mührünün vurulduğuna dair yer alan bilgi Peygamberimizin 12 yaşında gerçekleștirdiği Şam seferi sırasında rahip Bahîrâ ile tanışmasından önce gerçekleşmiştir.91 Burada akla hem doğumda hem de sonrasında bu mühür vurulmuş olamaz mı sorusu gelmektedir. Çünkü şakk-ı sadr hadisesinin dahi bir kaç kez gerçekleşmiş olabileceği yönünde muhtelif rivayetler mevcuttur. Bu da akla nübüvvet mührünün doğuştan olmakla birlikte sonradan bir kez daha vurulmuş olma ihtimalinin de olabileceğini getirmektedir. Bu bağlamda Bahîrâ hadisesi ile ilgili rivayet sadece yorum üzerinden değerlendirilebilir ve varsayımlarla sınırlı kalır.

Bir başka rivayette, Ebû Rimse et-Teymî'nin, nübüvvet mührüne tabiî bir ben olarak gösterdiği yaklaşım ${ }^{92}$ da bir cihetten düşünüldügünde, mührün doğuştan olduğunu akıllara getirebilir ancak bu da yorumdan ibaret bir yaklaşım olmaktan öte gitmeyecektir. Bu bağlamda Benî Âmir kabilesine mensub olan bir adamın da Ebû Rimse gibi tabiplik iddiası ile kürek kemikleri arasındaki bene müdahale etmek isteyişi de, nübüvvet mührü diye adlandırılan oluşumun doğuştan var olan bir ben şeklinde düşünülmesine imkân tanımaktadır.

Nübüvvet mührünün doğuştan olduğu ile ilgili tek sarih ifade doğum gecesinde bir Yahudi'nin şahitliğine dair olan rivayettir. Bu rivayeti destekleyici başka bir rivayet bize ulaşmamıştır. Doğum esnasında bu mührün var olduğunu kabul ettiğimizde sonradan vurulduğu yönündeki rivayetleri de mührün birkaç kez vurulmuş olabileceği şeklinde kabul etmek gerekir mi sorusuna cevabımız birkaç mührün varlığından bahseden tek bir rivayet bile mevcut değildir. Ancak sonradan vurulduğu yönündeki rivayetlerde göğsün yarılmasından bahsedildiğinden aslında sırtında herhangi bir mühürleme işlemi söz konusu değildir. Bu bağlamda nübüvvet mührünün doğuştan gelen bir alamet olduğunu kabul etmek gerekir.

\subsection{Nübüvvet Mührünün Vurulmasını Hz. Peygamber'in Göğsünün Yarılması Olayı İle İrtibatlandıran Rivayetler}

Hz. Peygamber'in sırtında bulunan nübüvvet mührü diye nitelendirilen benin doğuştan meydana gelmediği, sonradan melekler yahut insan görünümlü nuranî varlıklar tarafından göğsünün yarılıp kalbinin yıkanmasının ardından göğsünün kapatılmasına müteakip vurulduğu yönünde kaynaklarımızda rivayetler mevcuttur.

91 İbn İshak, Sîretü İbn İshak, 54-55; İbn Hișâm, es-Sîretü'n-Nebeviyye, 1/48; İbn Hibbân, es-Sîretü'nNebeviyye, 58-59; Ebû Nuaym, Delâilü'n-Nübüvve, 168-172; İbn Seyyidünnâs, 'Uyûnü'l-eserer, 1/105111.

92 Ahmed b. Hanbel, el-Müsned, 2/227. 
Hadis kaynaklarımızda Hz. Peygamber'in kalbinin yarılması ile ilgili rivayetler bizlere; Enes b. Mâlik, ${ }^{93}$ Übeyy b. Ka'b, Ebû Zer el-Gıfârị̂̂", Mâlik b. Sa'sa'95 ve Utbe b. Abd e-Sülemî ${ }^{96 i s i m l i ~ s a h a ̂ b i ̂ ~ r a ̂ v i l e r i ~ a r a c i l ı g ̆ ı y l a ~ u l a s ̧ m ı s ̦ t ı r . ~}$

Resûlullah'ın sütannesi Halîme'nin yanında iken dört- beș yașlarında, on küsur yaşlarında, vahyin başlangıcından önce olmak üzere üç defa gerçekleştiğine dair farklı rivayetler vardır. Bu rivayetler şakk-ı sadr hadisesi bağlamında kaynaklarımızda yer almaktadır. ${ }^{97}$

Sütannesi Halîme'nin yanında şakk-ı sadr hadisesinin gerçekleştiğini aktaran rivayetin muhtasarı, İbn Sa'd'ın Tabakât'ında ${ }^{98}$ mevcuttur.

Burada dikkat çeken nokta ise şakk-ı sadr hadisesi esnasında karın yahut kalp bölgesi kapatıldıktan sonra bu konuyu İbn Sa'd gibi ele alan Taberînnin rivayetinde nübüvvet mührü şeklinde olmaksızın mührün vurulduğu ile ilgili "Kalbimi mühürledi." şeklinde sarîh bir ifadeye rastlanmasına rağmen İbn Sa'd 'in Tabakât'ında böyle bir ifadeye "mühür vuruldu" şeklinde dahi rastlanmamasıdır. Fakat başka bir ilginçlik ise İbn Sa'd'ın bu rivayeti "vahiy öncesinde Resûlullah'ın nübüvvet alametlerinin zikri" başlığının altında vermesidir. Acaba neden İbn Sa'd, rivayetin içinde nübüvvet mührü geçmemesine rağmen bu bahsi nübüvvet alameti olarak ele almıştır? Rivayetin öncesine ve sonrasına baktığımızda da bu sorunun cevabını bulamamaktayız. Ancak şöyle bir açıklama mümkün görünüyor ki İbn Sa'd, salt olarak şakk-ı sadr olayını, yani peygamberlikten önceki meleklerin gelişi ile kalbin yarılması ve yıkanması olayını nübüvvetin alameti olarak gördüğünden bu şekilde zikrederek rivayet etmiştir.

İbn Sa'd 'ın ve Taberînnin rivayeti aktardığı râviler başka başkadır. Rivayetlerdeki farklılıkların başlıca sebebi budur. Ancak burada da hangi rivayetin sıhhat taşıdığı sorusu cevap beklemektedir. İbn Sa'd siyer kaynaklarının en eskisi olmasının yanında siyer klasikleri arasında olan Taberî̀nin de rivayeti yabana atılacak değildir. Ancak Taberî’nin rivayeti daha zayıf görünmektedir.

Şakk-ı sadr olayı bağlamında nübüvvet mührü ile ilgili olarak klasik kaynaklarımızdan Diyarbekrî'nin Tarih'inde de bu bahis üzerine bilgiye rastlanmaktadır. Diyarbekrî, Ebû Zer el-Gıfârî̀nin nübüvveti Peygamberimizin nasıl idrak ettiği üzerine sorduğu soruya mukabil Peygamberimiz sütannesinin yanında iken meleklerin gelişi ve kalbini yıkamaları olayını aktarmaktadır. Diyarbekrî rivayetinde "mühür vuruldu" ibaresi yer almaktadır. Diyarbekrî rivayetin devamında bu mühür ifadesini nübüvvet mührü şeklinde ifade ederek açılamaktadır. ${ }^{100}$

Buhârî, “Tevhid”, 37; Müslim, “İman”, 261.

İbn Asâkir, es-Sîretü'n-Nebeviyye, 3/261.

Müslim, "İman", 264.

6 Ahmed b. Hanbel, el-Müsned, 5/185.

97 Erdinç Ahatlı, "Nübüvvet Mührü" (Tarihî Süreçteki Algılanması ve Anlamlandırılması)", Sakarya Üniversitesi İlahiyat Fakültesi Dergisi 3 (2001), 283.

98 Ebû Abdullah Muhammed b. Sa'd b. Menî el-Hâşimî İbn Sa'd, es-Sîretü'n-nebeviyye Mine't-Tabakâtu'lKübrâ, (Kahire 1358), 1/131.

99 Taberî, et-Tarih, 2/304-305.

100 Hüseyin b. Muhammed b. Hasan Diyarbekrî, Târîhu'l-Hamîs fî Ahvâli Enfesî Nefîs (y.y, 1302), 1/256.

https://dergipark.org.tr/tr/pub/atebe 
Süheylî de Diyarbekrî gibi nübüvvet mührünün şakk-ı sadr olayı ile vurulduğu kanaatindedir. Bunun için Ebû Zer el-Gıfârînnin rivayet ettiği hadisi delil getirmektedir.101 Diyarbekrî'de yer alan ifadelerin aynısı ile rivayeti aktaran Süheylî̀nin rivayetinde tek bir farklılık gözlemlenmektedir. 0 da "Mekke vadisine yakın bir yer" (bathai Mekke) ifadesidir. Bu ifade Diyarbekrî’nin rivayetinde yer almamaktadır. Ancak mühür ile alakalı olan kısım bizi ilgilendirmektedir ki o da "ve ce'ale'l-hâteme beyne ketefeyhî" șeklinde ortak bir ifade kullanımıdır. Burada "mühürlendi" şeklinde yer almakla birlikte nübüvvet kelimesi geçmemektedir. ${ }^{102}$

Taberî, Süheylî ve Diyarbekrî rivayetlerinde yer alan "mühürlendi" ifadesinin ilk etapta daha erken bir kaynak olan İbn Sa'd'da görülmemesi zaman içerisinde metinlere eklemeler yapılmış olabilir düşüncesine bizi sevk etmektedir. Fakat Utbe b. Abd es-Sülemî kanalıyla gelen İbn İshak rivayetinde şakk-ı sadr hadisesi ile peygamberlik mührünün vurulduğundan "Sonra hâtemü'n-nübüvve ile mühürledi." şeklinde bahsedilmektedir.103 İbn Sa'd 'ın eserinde, İslâm tarihinin günümüze ulaşan ilk kaynağı kabul edilen İbn İshak rivayetinde geçen "Hâtemü'n-nübüvve ile mühürledi." ifadesinin yer almaması bir kaç cümle önce ele aldığımız İbn Sa'd 'ın metnine ekleme yapılmış olabilir tezini çürütmüştür. Kaynak kronolojisi bakımından İbn İshak'ta yer alan rivayetin İbn Sa'd'da yer almaması ve farklı bir anlatımın varlığı Tabakât yazarının rivayeti makul görmemesi sebebiyle eserine almaması şeklinde düşünülebilir. Taberî, Süheylî ve Diyarbekrî rivayetleri ise İbn İshak rivayeti ile görüldüğü üzere mutabıktır.

İbn Hacer, Fethu'l-Bârî adlı Buhâri şerhinde "Bâb u Hâtemü'n-Nübüvve" başlığı altında Utbe b. Abd es-Sülemî̀ den aktarılmış olan bu hadisi ele almaktadır. Ve hadisin son cümlesi olan "Hâtemü'n-nübüvve ile mühürledi." kısmını göğsündeki yarılmanın izi olarak değil de sırtındaki mührün izi olarak değerlendirmiştir. Nevevî ve diğerleri, bu izi şakkın izi olarak söylediklerini ancak böyle olmadığını bu izin mührün izi olduğunu beyan etmiştir ${ }^{104}$ ve bu iddiasını desteklemek için Şeddâd b. Evs'in hadisinden bahsetmiştir. ${ }^{105}$

Hz. Peygamber'in sırtına mührün vurulması olayı ile ilgili olarak dikkat çeken bir diğer husus da göğsün yarılmasının bir kez daha gerçekleştiği rivayet edilen isrâ ve mi'rac hadisesidir. Ancak bu hadisede gögüs yarılmasından bahsedilse de mührün vuruluşu ile ilgili bir ibare yer almamaktadır.106 Hadis kaynaklarımızda yer alan rivayetleri taradığımızda da isrâ ve mi'rac bölümlerinde şakk-ı sadr olayını aktaran rivayetlerin metinlerinde nübüvvet mührüne ilişkin sarîh bir ifadeye rastlanmamaktadır. ${ }^{107}$

101 Süheylî, er-Ravżü'l-Ünüf, 1/319.

102 Süheylî, er-Ravżü'l-Ünüf, 1/320.

103 İbn İshak, Sîretü İbn İshak, 27-28; Ahmed b. Hanbel, el-Müsned, 4/185; Taberî, et-Tarih, 2/161-162.

104 İbn Hacer, Fethu'l-Bârî bî Şerhi Sâhihi'l-Buhârî (Beyrut: t.y), 6/561.

105 İbn Hacer, Fethu'l-Bârî, 6/562; Erdinç Ahatll, "Nübüvvet Mührü" (Tarihî Süreçteki Algılanması ve Anlamlandırılması)", Sakarya Üniversitesi İlahiyat Fakültesi Dergisi/3 (2001), 290.

106 Süyûtî, Hasâis, 113; Buhârî, "Tevhid", 37; "Salât", 1, "Hac", 75; "Fezailu's-Sahâbe", 71; Ebû Abdurrahman Ahmed b. Şuayb Nesâî, es-Sünenü'l-Kübrâ (Beyrut:1991), "Salât", 1-2.

107 Ahmed b. Hanbel, el-Müsned, 4/208; Buhârî, "Tevhid", 37; Buhârî, "Salât", 1; Müslim, "İman”, 263264; Tirmizî, "İnşirâh", 83. 
Bunun yanı sıra şakk-ı sadr olayı ve nübüvvet mührünün vurulması ile ilgili ilk vahyin indirilişi sırasında Hz. Peygamber Hirâ mağarasında iken bu hadisenin gerçekleștiği rivayeti de kaynaklarımızda mevcuttur.108

Bu hususta en dikkat çeken ayrıntı şakk yahut şerh diye nitelenen olayların tamamı göğüs bölgesinde gerçekleşmesine rağmen sırtta kürek kemikleri arasında mevcut olduğu söylenilen nübüvvet mührünün mevcudiyeti ile bütünleștirilmesidir.

Nübüvvet mührünün doğuştan olduğuna dair elimizde hadiseye direkt delalet eden bir rivayet olmasına karşın sonradan sırtına vurulduğu ile ilgili bir rivayet bulunmamaktadır. Sonradan vurulduğunu serd eden rivayetlerin tamamı mühürleme işleminin şakk hadisesi bağlamında göğüs bölgesinde gerçekleştiğini vurgulamaktadır. Sütannesinin yanında ve ilk vahyin gelişinde Hirâ mağarasında gerçekleşen göğsünün yarılması rivayetlerinde rastladığımız "Mühürlendi, nübüvvet mührü vuruldu." ifadelerini kalbin yıkanması ve göğsün kapanırken mühürlenmesi işlemi olarak ele almak tenakuzu neticelendirecektir.

\subsection{Nübüvvet Mührünün Tabiî ve Mucizevî Şekillerde Algllanması ve Bu Algıların Tahlili}

Daha önce ele almış olduğumuz rivayetler içerisinden bazılarını nübüvvet mührünün tabiî ve mucizevî șekillerde algılanması mevzusu çerçevesinde kısaca zikrederek burada atıf usulü ile ele almak durumundayız. Çünkü rivayetlerin bu cihetle delaletleri de söz konusu olmaktadır.

Ehl-i kitaba ait semavî kitaplarda geleceği müjdelenen son Peygambere ${ }^{109}$ dair rivayetlerde fizikî özelliklere ${ }^{110}$ değinenler içinde nübüvvet mührüne de değinildiğini bilmekteyiz. Bu bağlamda Ehl-i kitap üzerinden aktarılan rivayetlerin nübüvvet mührüne mucizevî bir anlam yüklediğini görmek mümkündür. Bu ben, bir alamettir. Gelecek olan son peygamberin peygamberlik alametidir. Ehl-i kitap bu ben aracıllğı ile son peygamberi tespit edeceğine öyle inanmıştır ki rivayetlerde Peygamberimizin hem doğumunda hem de Şam'ın Busrâ'sına yaptığı yolculukta Ehl-i kitap mensuplarının sırtına baktıklarını görmekteyiz. Selmân-ı Fârisî̀nin Müslüman oluşu da yine aynı şekilde yani Peygamberimizin sırtına bakıp mührü görmesi üzerine gerçekleşmiştir. ${ }^{111}$

Hz. Peygamber'in kürek kemikleri arasında bulunan bu benin olağanüstülük taşıdığına vurgu yapan hadiselerin başında, Peygamberimizin dünya değiştirdiği esnada odasında bulunan ve vefatını anlamak için sırtına elini sokarak nübüvvet mührünün gidip gitmediğini kontrol eden ve eline ben denk gelmeyince Peygamberimizin vefatına şahitlik eden Esmâ binti Umeys'in rivayeti gelmektedir. ${ }^{112} \mathrm{Bu}$ rivayet nübüvvet mührünü bir mucize olarak görenlerin görüşünü destekler mahiyettedir. Öte yandan Cibril-i Emîn'in

108 Ebû Dâvûd Süleyman b. Davud Tayâlisî, Müsnedü Ebî Davud et-Tayâlisî, (Haydarabad:1321), 215-216, no: 1539.

109 Yu.15:28; Yar.12:1-3; Yas.18:18; Dan.7:13-14; Mez. 45:3-17, Mal. 4:5.

110 Süyûtî, Hasâis, 113.

111 İbn İshak, Sîretü İbn İshak, 68, 69; İbn Hişâm, es-Sîretü’n-Nebeviyye 1/177; İbn Hıbban, es-Sîretü’nNebeviyye, 58-59; Beyhakī, Delâilü'n-Nübüvve, 2/82-91, 95, 97; İbn Seyyidinnâs, 'Uyûnü'l-Eșer, 1/105111; Ali b. Rabben et-Taberî, ed-Din ve'd-Devle, 146-147.

112 Beyhakī, Delâilü'n-Nübüvve, 7/219; Şâmî, Sübülü'l-Hüdâ $2 / 73$. 
gelerek kalbini yarıp sonrasında mühürlemesi hadisesi,113 şakk-ı sadr üzerine gelen rivayetler hep mucizevî olarak nübüvvet mührünün algılandığının göstergesi olan rivayetlerdir.

Nübüvvet mührünü doğuştan tabiî bir ben olarak görenler için nübüvvetle ve nübüvvete binaen bahședilen gaybî ve ilmî ihsanlarla alakalı bir durum söz konusu değildir. Mührün tabiî bir ben gibi algılandığını gösteren rivayetlerin başında ise Teymü'rRebâb kabilesine mensup olan Ebû Rimse et-Teymînnin Hz. Peygamberi ziyarete gelerek sırtındaki beni yahut ura benzeyen yumruyu göstermesini istemesi, Resûlullah'ın ne yapacağını sorması üzerine cerrahî bir müdahale ile onu almayı teklif etmesi hadisesi gelmektedir. ${ }^{114} \mathrm{Bu}$ rivayet içerisinde her insanda bulunabilecek bir ben yahut ur tarzı bir yumru anlayışı mevcuttur.

Bu bağlamda nübüvvet mührünün tabiî ve mucizevî algılanışlarıyla ilgili olarak ağırlığın rivayetler bakımından mucizevî bir nitelik taşıdığı yönünde olduğunu ancak bu rivayetlerin her birinin ayrı ayrı eleştirildiğini, yorumlandığını, metin-sened bakımlarından bir takım sıkıntılarının olduğu yönünde tenkit edildiklerini zikrettiğimiz rivayetlerle yeri geldikçe aktarmış olduk.

Bunlar elbette yorumlardır ve bütün yorumların olduğu gibi bu yorumların da inanan ve savunanları olacaktır. Peki asıl olan nedir?

Mucizeler konusu sınırlı bir kesim için ihtiyaç duyulan aslen dar bir mevzudur. Diğer bir takım mucizeler de dâhil olmak üzere kaynaklarımızda bu konular hep ihtilaflı şekilde yer almıştır. Hz. Peygamber'in peygamberliğini kabul edenler için nübüvvet mührünün mucizevî yönü olup olmaması bir anlam ifade etmemektedir. Çünkü böyle bir işaret ile iman edilecek bir nübüvvet söz konusu değildir. Ancak peygamberlerin gönderildikleri topluluklar için yer yer göstermiş oldukları mucizeler elbette mevcuttur. Hz. Peygamber'in bir iman daveti şeklinde kimseye sırtını açıp mucize şeklinde gösterdiği bir mühür/ben söz konusu olmamıştır. Bu sebeple gerek Ehl-i kitabın beklentisine cevap veren varlığı ile gerekse ashabın aktardığı rivayetlerdeki anlatımlar ile nübüvvet mührünün, alışılagelmiş mucizelerden biri olarak değil ancak delâlet ve hasâis anlamında bir alamet, işaret olarak kabul edilmesi gerekir kanaatindeyiz. Yoksa ki sıradan bir benin İslâm tarihi boyunca birçok rivayete konu olması ve ayırıcı vasıfları ile tarifi durumu sağlam bir zemine oturmayacaktır.

\section{Sonuç}

Hz. Peygamber'in iki kürek kemiği arasında, görgü şahitlerinin algılama ve anlatma şekillerine göre birbirinden farklllık gösteren benzetmelere göre bir benin veya irice tabir olunan bir et parçasının olduğu açıktır. Bu et parçası veya ben diye tarif olunan ancak nübüvvet mührü olarak tabir edilen mevcudiyetin değerlendirilişinde ise ciddi farklılıklarla karşılaştık. Varoluş zamanı ve bu zamana bağlı olarak var oluş biçimi üzerine rivayet farklılıklarını çalışmamız dâhilinde yansıttık. Böylece doğuştan vurulmuş olması yahut sonradan vurulması arasında alamet olup olmamasına etki edecek bir durumun söz

113 Süyûtî, Hasâis, 113.

114 Ahmed b. Hanbel, el-Müsned, 2/227-228. 
konusu olmadığını tespit etmiş olduk. Çünkü rivayetler her iki durum için de alamet olarak görülmesini destekler durumdaydı.

Peygamberimizin ağzından, sırtındaki bu ben hakkında olağanüstülüğüne dair açık ifadeler bugüne ulaşmamıştır. Bu durum benin tabiî ve fizyolojik bir yapıya sahip olduğunu düşünenlerin görüşlerini güçlendirmektedir. Bu konuya dair sahih rivayetler ise sadece nübüvvet mührünün çeşitli tasvirlerini bize aktarmaktadır. Bu tasvirler, görenlerin algısına dayandığı için farklılık arz etse de aşağı yukarı tevhid edilebilecek bir tarif bugün için elimizde mevcuttur. Hâsılı Peygamberimizin sırtında ben şeklinde bir nübüvvet mührünün var olduğu açıktır. Bu mührün Ehl-i kitabın beklentisi doğrultusunda şemâil ve delâil kapsamında yani fiziksel manadaki varlığıyla nübüvvete delalet eden bir hüviyete sahip olduğu da rivayetlerde görülmektedir.

Varlığının tabiî ve fizyolojik bir șekilde var olup olmadığı; mucizevî bir tarzda vurulup vurulmadığı gibi hususlardaki rivayetler farklılık taşısa da tabiî varlığı ile nübüvvet alameti oluşundan öte bir mucizevî yönünden bahsetmek doğru olmayacaktır.

Özetleyecek olursak İslâm tarihi içerisinde farklı kabullere ve görüşlere açık bir şekilde değerlendirilmiş olan nübüvvet mührünü, Peygamberimiz hakkında diğer insanlardan farklı mümeyyiz/ayırt edici bir vasıf olarak ele almak; nübüvvet alameti şeklinde ancak fiziksel olarak tabiî bir tarzda kabul etmek gerekir. Kitap ehlinin bu konudaki bekleyiși, gerek hadis gerekse siyer kaynaklarındaki nübüvvet mührü ifadeleri bizi bu noktaya sevk etmiştir.

\section{Kaynakça}

Ahatll, Erdinç. "Nübüvvet Mührü" (Tarihî süreçteki algılanması ve anlamlandırılması). Sakarya Üniversitesi İlahiyat Fakültesi Dergisi/3 (2001), 281-302.

Ahmed b. Hanbel, Ahmed Ebû Abdillâh eş-Şeybânî. el-Müsned. 6 Cilt. İstanbul: 1313.

Ali b. Rabben et-Taberî. ed-Din ve'd-Devle fí İsbâti Nübüvveti'n-Nebiyyi Muhammed Sallellâhu Aleyhi ve Sellem. nşr. Âdil Nüveyhıd. Beyrut: 1982.

Arslan, İhsan. "Vahiy Bağlamında Rahip Bahîrâ Olayının Değerlendirilmesi". Recep Tayyip Erdoğan Üniversitesi Sosyal Bilimler Dergisi 4/8 (2018), 313-341.

Belazûrî, Ebu'l-Hasen Ahmed b. Yahyâ b. Câbir b. Dâvûd. Ensâbü'l-Eşrâf. thk. Muhammed Hamidullah. Mısır: 1959.

Beyhakī, Ebû Bekir Ahmed b. Hüseyin. Delâilü'n-Nübüvve ve Ma'rifetü Ahvâli Sâhibi'şŞerîa. nşr. Abdülmu'tî Kal'acî. 7 Cilt. Beyrut: 1985.

Buhârî, Ebû Abdullah Muhammed b. İsmâîl. el-Câmi'u'ṣ-Sahîh. nşr. Muhammed Züheyr b. Nasr. 8 Cilt. İstanbul: 1979.

Ceyhan, Nejla. Klasik İslam Tarihi Kaynaklarında Nübüvvet Mührü (Konya: Necmettin Erbakan Üniversitesi, Sosyal Bilimler Enstitüsü, Yüksek Lisans Tezi, 2015.

Diyarbekrî, Hüseyin b. Muhammed b. Hasan. Târîhu'l-Hamîs fí Ahvâli Enfesî Nefîs. 2 Cilt. 1302.

Ebû Dâvûd, Süleyman b. Eș'as es-Sicistânî. Sünenü Ebî Davud. 5 Cilt. İstanbul: 1981.

https://dergipark.org.tr/tr/pub/atebe 
Ebû Nuaym el-İsfahânî. Delâilü'n-Nübüvve. nşr. Muhammed Ravvâs Kal'acî-Abdülber Abbâs. Haleb: Dâru'n-Nefâis, 1999.

Eser, Mithat. "Hz. Peygamber'in Bir Bulut Tarafından Gölgelenmesine Dair Rivayetlerin Değerlendirilmesi". İslamî Araştırma Dergisi 22/1 (2011), 44-54.

Halebî, Nuruddin Ebu'l-Ferec Ali b. Burhâneddin İbrahim b. Ahmed. İnsanü'l-Uyûn fî Sireti'l-Emîni'l-Me'mûn. 3 Cilt. Kahire: 1292.

İbn Asâkir, Ebu'l-Kâsım Ali b. el-Hasan b. Hibetullah eş-Şâfiî. es-Sîretü'n-Nebeviyye. 4 Cilt. Beyrut: 2001.

İbn Hacer, Şihâbüddin Ebü'l-Fadl Ahmed b. Ali b. Hacer el-Askalânî. el-İsâbe fî-Temyîzi'sSahâbe. 9. Cilt. Beyrut: Dâru'l-Kütübi'l-İlmiyye, 2005.

İbn Hacer, Şihâbüddin Ebü'l-Fadl Ahmed b. Ali b. Hacer el-Askalânî. Eşrefü'l-Vesâil ilâ Fehmi'ş-Şemâil, nşr. Muhammed Ali Beydûn, Beyrut 1998.

İbn Hacer, Şihâbüddin Ebü'l-Fadl Ahmed b. Ali b. Hacer el-Askalânî. Fethu'l-Bârî bî Şerhi Sâhihi'l-Buhârî, 13 Cilt. Beyrut: ts.

İbn Hibbân, Ebû Hâtim Muhammed b. Hibbân b. Ahmed el-Büstî. es-Sîretü'n-Nebeviyye Ve Ahbârü'l-Hulefầ'. Beyrut: 1987.

İbn Hişâm, Ebû Muhammed Abdülmelik. es-Sîretü'n-Nebeviyye.. thk. Mustafa es-Sekkâİbrahim el-Ebyarî-Abdülhafîz Şelebî. 4 Cilt. Beyrut: 1992.

İbn İshak, Muhammed b. İshak b. Yesâr. Sîretü İbn İshak el-Müsammâ bî Kitabi'l-Mübtede' ve'l-Meb'as ve'l-Meğazî. nşr. Muhammed Hamidullah. Konya: 1981.

İbn Kesîr, Ebu'l-Fidâ İsmâîl b. Ömer el-Dımeșkî. el-Bidâye ve'n-Nihâye. 7. Cilt. Mısır: 1932.

İbn Sa'd, Ebû Abdullah Muhammed b. Sa'd b. Menî el-Hâşimî. es-Sîretü'n-Nebeviyye Mine'tTabakâtu'l-Kübrâ. 4 Cilt. Kahire: 1358.

İbn Seyyidünnâs, Ebu'l-Feth Muhammed b. Muhammed el-Yemurî. Uyûnül-Eser fí Funûnu'l-Meğâzî ve'ş-Şemâil ve's-Siyer. nşr. Muhammed el-Iydu'l-HatrâviMuhyîddin Mestû. 2 Cilt. Beyrut: 1992.

Kādî İyâz, Ebü'l-Fadl İyâz b. Musa el-Yahsubî. Kitabü'ş-Şifâ bî Târîfi Hukûki'l-Mustafâ. Beyrut: 2000.

Kitâb-ı Mukaddes. İstanbul: Boyacıyan Agop Matbaası, 1949.

Köksal, M. Âsım. İslâm Tarihi. 18 Cilt. İstanbul: 1987.

Kur'ân-ı Kerîm Meâli. çev. Halil Altuntaş - Muzaffer Şahin. Ankara: Diyanet İşleri Başkanlığı Yayınları, 3. Basım, 2009.

Kuşeyrî, Ebu Kâsım Abdulkerîm b. Hevâzin. Menâhilü'ş-Şifâ ve Menâhilü's-Safâ bî-Tahkikî Kitabî Şerefi'l-Mustafâ. 6 Cilt. 2003.

Mâlik b. Enes. el-Muvatța’. 2. Cilt, Beyrut: Dâru İbn Kesîr, 2000.

Mercânî, Ebû Muhammed Afiffüddîn Abdulmelik. Behcetü'n-Nüfus ve'l-Esrâr. 2 Cilt. Mısır: Dâru'l-Ġarbi'l-İslâmî, 2002. 
Klasik İslâm Tarihi Kaynaklarında Nübüvvet Mührü

Mevlana Şiblî Numânî. Âsr-ı Saadet. çev. Ömer Rıza Doğrul. 4 Cilt. İstanbul: Eser Neşriyat, 1978.

Müslim, Ebü'l-Huseyn Müslim b. Haccâc el-Kuşeyrî en-Nîsâbûrî. el-Câmi'u's-Sahîh. nşr. Nezr Muhammed el-Fâryâbî. Dâru't-Taybe, 2006.

Nebhânî, Yûsuf b. İsmâil. el-Fedâilü'l-Muhammediyyeti'l-letî Feddalehullahu Biha (s.a.v) Alâ Cemî'i'l-Beriyye. Beyrut: ts.

Sinanoğlu Mustafa. "Nübüvvet Mührü". Türkiye Diyanet Vakfi Ansiklopedisi. 23/291-293. İstanbul: TDV Yayınları, 2007.

Süheylî, Abdurrahman b. Abdullah. er-Ravdu'l-Ünüf fî Tefsirî́s-Sîreti'n-Nebeviyye ve Me'ahu's-Sîretü'n-Nebeviyye. thk. Abdullah el-Minşâvî. 4 Cilt. Kahire: 2008.

Süyûtî, Celâlüddin Abdurrahman. Tehzîbu Hasâisu'n-Nübüvvetü'l-Kübrâ. Beyrut: Darü'lBeşâirü'l-İslâmiyye, 1410.

Şâmî, Muhammed b. Yûsuf es-Sâlihî. Sübülü'l-Hüdâ ve'r-Reşad fî Sîrati Hayri'l-ıbâd. nşr. Mustafâ Abdülvâhid. 8 Cilt. Kahire: 1990.

Taberî, Ebû Ca'fer Muhammed b. Cerîr. Târîhu't-Taberî (Târîhu'l-Ümem Ve'l-Mülûk). nşr. Muhammed Ebu'l-Fadl İbrâhîm. 10 Cilt. Kahire: ts.

Tayâlisî, Ebû Dâvûd Süleyman b. Dâvûd. Müsnedü Ebî Davud et-Tayâlisî. Haydarâbâd: 1321.

Tirmizî, Ebû Îsâ Muhammed b. İsâ. Sünenü't-Tirmizî. 5 Cilt. İstanbul: Çağrı Yayınları, 1981.

Zehebî, Ebû Abdullah Șemsüddin Muhammed b. Ahmed b. Osman. Târîhu'l İslâm ve Vefeyâtu'l-Meșâhîr ve'l-A'lâm. 44 Cilt. nşr. Ömer Abdü's-Selâm Tedmurî. Beyrut: 1994.

Zehebî, Ebû Abdullah Şemsüddin Muhammed b. Ahmed b. Osman. Mizânü'l-I'tidâl fî Nakdi'r-Ricâl, 4 Cilt. Beyrut: ts.

Zürkānî, Muhammed b. Abdülbâkî. Şerhu'l-'Allâme ez-Zürkânî 'ale'l-Mevâhibi'l-Ledünniye li'l-Kastalânî. 14 Cilt. Beyrut: 1996.

https://dergipark.org.tr/tr/pub/atebe 